\title{
Information Exchange and Environmental Justice
}

\author{
Gloria G. Horning \\ Northern Arizona University, Flagstaff, AZ, USA \\ Gloria.Horning@nau.edu
}

\begin{abstract}
The Environmental Justice Movement is an aggregate of community-based, grassroots efforts against proposed and existing hazardous waste facilities and the organizations that assist them. The movement has created a context in which low-income communities and people of color are able to act with power. Using interviews, participant observation, and various archival records, a case study of the organization HOPE located in Perry, Florida, was developed. The case compared key factors in community mobilization and campaign endurance. Special attention was paid to the process of issue construction, the formation of collective identity, and the role of framing in mobilizing specific constituencies.

In the case of the P\&G/Buckeye Pulp Mill where the community face hazardous surroundings. Environmental inequality formation occurs when different stakeholders struggle for scarce resources within the political economy and the benefits and costs of those resources become unevenly distributed. Scarce resources include components of the social and natural environment. Thus the environmental inequality formation model stresses (1) the importance of process and history; (2) the role of information process and the relationship of multiple stakeholders; and (3) the agency of those with the least access to resources.

This study explores the information exchange and the movement's identity on both an individual and group level. When people become involved in the movement they experience a shift in personal paradigm that involves a progression from discovery of environmental problems, through disillusionment in previously accepted folk ideas, to personal empowerment.
\end{abstract}

Keywords: Communications, Environmental Justice, Social Networks

\section{Introduction}

"Never doubt that a small group of thoughtful, committed people can change the world, it's the only thing that ever has"

(Margaret Mead, 1962)

Lois Gibbs, the founder of Citizens Clearinghouse for Hazardous Waste, stated, “The truth won't stop the poisoning, but organization and information exchange within a community will” (1995).

Material published as part of these proceedings, either on-line or in print, is copyrighted by Informing Science. Permission to make digital or paper copy of part or all of these works for personal or classroom use is granted without fee provided that the copies are not made or distributed for profit or commercial advantage AND that copies 1) bear this notice in full and 2) give the full citation on the first page. It is permissible to abstract these works so long as credit is given. To copy in all other cases or to republish or to post on a server or to redistribute to lists requires specific permission from the publisher at Publisher@InformingScience.org
Environmental justice, often used interchangeably with the term environmental equity, refers to the distribution and effects of environmental problems and the policies and processes to reduce differences in those who bear environmental risks. In a general sense, it includes concern for 
disproportionate risk burden placed upon any population group, as defined by gender, age, income and race. To date, most attention has been directed at environmental justice with respect to income and race. In this context, a definition of environmental justice is the "fair treatment of people of all races, cultures and income with respect to the development, implementation and enforcement of environmental laws, regulations, programs and policies" (Bullard, 1996).

There has been increasing concern over disproportionate health impacts on minority and lowincome populations with respect to environmental conditions. The debate on this issue, known as environmental justice, is marked by many fault lines in American life. First, there are disputes between various organizations, private and government regarding the relationship between pollution and disease. Second, there are the volatile issues of race, class, and the historic grievances that go along with exposure to pollution and disease. Ever since the federal government began to address environmental hazards in the 1970s, "industries have sought to portray regulators as power-crazed bureaucrats whose senseless edicts are sucking the lifeblood out of the American economy” (Fagin \& Lavelle, 1996).

Third, there are conflicts over the environment and the tradeoffs necessary in protecting people and preserving nature, along with fostering reasonable economic development. In the mindset of many environmental activists, people of low social and economic value are at risk in a manner disappropriate to their numbers in the population.

Opposition to environmentalism developed with increasing pressure of property rights movements seeking to expand development of natural resources, and an environmental justice movement perceived to be concerned with issues and constituencies not addressed by mainstream environmental organizations (Bryant \& Mohai, 1992b). As a result of that opposition, the environmental movement in the United States has strengthened, and broadened through memberships in varied organizations and in the range of issues addressed.

The environmental justice movement is relatively young. Its origin is often traced to the protests held in Warren County, North Carolina, in 1982. Yet, many of the elements of the modern movement can be traced much farther back, at least to the Civil Rights Act of 1975 and the first environmental law of 1989.The biographical history of the environmental justice movement is quite different in some ways from that of other major movements, such as the traditional environmental and the civil rights movements. The environmental justice movement is largely decentralized, manifested in the activities of dozens or hundreds of local groups, rather than centralized, operating under the direction of large national organizations. As a result, many of the real heroes and heroines of the environmental justice movement are organizers or chairs of town, county, village, or parish organizations; they are people whose names are probably not well known outside of the environmental justice movement itself.

While possible adverse distribution of environmental impacts first became a concern in the 1980s, only in the last few years has there been sufficient information to begin to comprehend the extent of the problem. At least two different measures of environmental equity have been proposed. A "proximity-based" measure depends upon people's proximity to facilities that pose environmental hazards. It has been found that minorities and low-income groups are more likely to live close to hazardous waste facilities. The second is a "risk- based" measure that goes beyond measurement of distance to the site and incorporates other factors such as the probability of an accidental release of chemicals, toxicity, level of exposure, the size of the area affected by a release and natural factors, such as wind direction (Bullard, 1995; United Church of Christ Commission for Racial Justice, 1992).

Center to the environmental justice issue is citizen involvement for more meaningful public participation in "solution activities" (Bullard, 1993; United Church of Christ Commission for Racial Justice, 1992). "Environmental justice demands the rights to participate as equal partners at every 
level of decision-making including needs assessment, planning, implementation, enforcement and evaluation (Dowie, 1995). As such, environmental justice groups may be the vanguards of democratic revitalization -- demanding the right to information, access to public forums, and a voice in the decision-making process. The most "significant feature of the grassroots movement-and what distinguishes it from other movements-is it strong belief in the right of citizens to participate in environmental decision-making” (Dowie, 1995).

For 35 years, small environmental grassroots organizations have sprung up across the United States. Studies of utilization of information of these groups fall short in examining the manner in which the decision-making process embraces the community and/or neighborhood. Robert Bullard, considered the father of the environmental justice movement, said the movement must "take a multi-media approach and it must involve the public and particularly impacted communities in decision-making” (Bullard, 1998).

\section{Citizen Participation}

Communities across the United States and the World are becoming more conscious of environmental justice. At the heart of environmental activism is the strong belief in the right of citizens to participate in environmental justice movement and a strong belief in the right of citizens to participate in the environmental decision-making. Community right-to-know laws, citizen enforcement provisions in federal and state legislation, and local input in waste clean-up as well as the location and placement of toxic releasing corporations are key issues to the environmental justice movement.

Rachel Carson's Silent Spring (1962) was the first publication to document the deadly carnage of the pesticide dichloro-diphenyl-trichloriethane (DDT) on the environment and on human life. She wrote, "The victims of DDT are every human being from the moment of conception until death" (Carson, 1962). This was becoming abundantly clear to her in the alarming increase in the use of pesticides following the end of World War II. There were reports of livestock found dead in their fields. There was well-documented and wide-spread damage to wildlife; poisoned birds were literally falling from the skies (Carson, 1962).

Carson in Silent Spring challenged the practices and views of the agricultural industry and government. She asserted that the indiscriminate use of DDT was poisoning not just "target" species but the environment itself, and called for an end to the misuse of this and other powerful toxins. Carson succeeded in building a strong scientific case for her thesis. She wrote, "We are engaged in a war against nature that will inevitably destroy us as well as our supposed enemies" (Carson, 1962).

Rachel Carson was discounted as a "hysterical woman, "and there were various attempts to discredit both her and her findings. Carson's meticulous research, however, left her detractors little room to maneuver (Dowie, 1996). Agricultural and trade journals attacked Silent Spring before it hit the shelves. Chemical companies attempted to discredit Carson and her findings, and threatened to pull ads from magazines and newspapers that gave Silent Spring favorable reviews (Byrnes, 1998). The assault on Silent Spring and her work, ironically, had the opposite effect. The biased, distorted attacks helped bring more attention to Carson's book, and attracted a large global audience.

Soon after publication she formed the first grassroots environmental group--Town Natural Resources Coalition (TNRC) and she is often hailed as the mother of modern environmentalism (Dowie, 1996). President John F. Kennedy discussed the book at a press conference and appointed a special panel to examine its conclusions (Byrnes, 1998). 
Starting in the late 1960s, the modern "environmental movement" began to take shape as activist lawyers and scientists came to the aid of citizens who were trying to ban the pesticide DDT. In response to the influence of Silent Spring, state legislatures introduced 40 bills regulating pesticides nationwide by the end of 1962. During the 1970s, Congress passed a dozen major environmental laws. In 1972, after much study and debate, the Environmental Protection Agency (EPA) banned the use of DDT. Four years later, Congress passed the Toxic Substance Control Act, banning or strictly controlling the use of many other pesticides and toxic chemicals (Byrnes, 1998).

Forty-two years have now passed since Carson's Silent Spring exposed the "onslaught of toxic chemicals that threaten the health and well-being of the American people" (Carson, 1962). But many have followed in her footsteps.

Lois Gibbs learned in 1978 that 20,000 tons of toxic chemicals were buried under her Niagara Falls, New York neighborhood, she tried to make sense of all the information and scientific names suddenly thrown at her. She began her work by drawing the nation's attention to Love Canal in western New York. There, Gibbs's children and other people living in houses or attending a school built over a toxic dump were stricken with liver damage, asthma, urinary tract disorders, immune system dysfunctions and rare blood diseases, such as the one that mimicked hemophilia and leukemia in Gibbs's daughter, Melissa.

Between 1978 and 1980 Gibbs led the Love Canal Homeowners Association of Niagara Falls in a victory that consisted of obtaining $\$ 120$ million in government assistance plus damages from Occidental Petroleum to test, clean up and relocate them from their neighborhood that had been poisoned with over 200 chemicals. These included as yet unnamed chemicals and known toxins like chloroform, dioxin, trichlorethane, tetrachlorethane, the banned pesticide Lindane and solvents like benzene.

On October 1, 1980 in a speech in New York State, former President Jimmy Carter acknowledged Gibbs as the "most important grassroots leader of the Love Canal residents." He said,

"Without her impassioned advocacy and dedication there might never have been a Love Canal emergency declaration and the agreement between the United States government and the government of the State of New York that permitted the state to purchase the homes of residents of the Love Canal area might never have come to pass" (Carter speech, 1980).

He went on to say,

"The whole question of the disposal of hazardous waste, especially toxic chemicals, is going to be one of the great environmental challenges of the [future.] As a nation we must look ahead [and] ... must make this resolution for our own sake and more importantly for the entire nation. There must never be in our country another Love Canal" (Carter speech, 1980).

Lois Gibbs went on to become the founder of Citizens Clearinghouse for Hazardous Waste (CCHW), and stated, “The truth won't stop the poisoning, but organization and information exchange within a community will” (1995). Gibbs sees the poison dioxin as a failure of selfgovernment and a failure of people to control corporations: "We can't shut down the sources of dioxin without finding the courage to change the way government works," she says. "We have to explore how people became powerless as the corporations became powerful. We have to figure out how to speak honestly and act collectively to rebuild our democracy”. After her ordeal at Love Canal, Gibbs received thousands of calls from people around the nation also facing environmental hazards. In order to help other people, she established CCHW. "I can provide something to people in a way that comes from personal experience I walked the walk and did it”, she said. 
Her organization teaches community groups and individuals the basics of advocacy such as writing letters, meeting with public officials and talking to corporations. She also helps people understand technical information in environmental studies.

"People get inspired by their own actions and all we really do is give them the path and frame it in a way that they see each step as a major victory”, said Gibbs (1999).

The dioxin campaign puts the grassroots environmental community squarely "in the face" of the biggest polluters in the nation, and it creates a "line in the sand"--a challenge to the government and to citizens facing life threatening issues in their backyards." We know that we are up against huge corporate power, but tackling the misuse of corporate power is what the 21st century is going to be about," says Ellen Connett, one of the leaders of the new grassroots campaign, and editor of the weekly, WASTE NOT(1996).

\section{Environmental Justice}

It is well documented that health differs by race and class. According to the U.S. Centers for Disease Control (1998), poor people and people of color get sick more often than people from middle and upper social classes, and pollution plays a complex role in these disparities. The combination of poverty and pollution amounts to "double jeopardy" according to the National Institute of Medicine, National Report (1999). The affected communities experience higher levels of exposure to environmental stresses in terms of both frequency and magnitude. They are less able to deal with these hazards as a result of limited knowledge of exposures and because of a disenfranchisement from information concerning their health. Of course their financial situation serves as a barrier in acquiring necessary knowledge and mustering adequate support.

In July, 1990 an Environmental Equity Workgroup was established within EPA to assess the evidence that environmental risks are not shared equally across populations. On February 11, 1994 President Bill Clinton signed Executive Order 12898, giving national priority to what previously had been a community-rooted movement, and creating an interagency Federal Working Group on Environmental Justice. In addition, state and federal agencies have developed strategies to identify adverse health and environmental effects upon minority and low income populations. The order directs each federal agency to make...

...”achieving environmental justice part of its mission by identifying and addressing, as appropriate, disproportionately high and adverse human health or environmental effects of its programs, policies, and activities on minority populations and low-income population” (Executive Order 12898).

Environmental justice ensures that all communities, including minority and low-income communities, live in a safe and healthful environment. The Environmental Protection Agency Office of Environmental Justice defines environmental justice as:

"The fair treatment and meaningful involvement of all people regardless of race, color, national origin, or income with respect to the development, implementation and enforcement of environmental laws, regulation and policies. Fair treatment means that no group of people, including racial, ethnic, or socioeconomic groups, should bear a disproportionate share of the negative environmental consequences resulting from industrial, municipal, and commercial operation or the execution of federal, state, local, and tribal programs and policies" (National Environment Policy Act, Section 309.1.3, 1998).

The heart of the National Environmental Policy Act (NEPA) is quality of life. Quality of life includes considering such issues as what kind of communities and what kind of jobs people want? Certain questions are posed regarding the kind of natural and man-made surroundings in which they live, shaping communities, creating jobs and enhancing this notion of quality of life. 
The National Environmental Policy Act describes the effect of a potential hazardous site upon a city, community, group of property owners, or individuals in terms of compatibility of use, zoning, community growth, and other factors associated with the public interest (Bullard, 1993).

Various solutions to the environmental justice problem have been proposed. These include: (1) toxics use reduction (pollution prevention), (2) improved stakeholder participation in the public environmental decision-making process, (3) improved access to environmental data and information, (4) increased research on health risks from exposure to toxics, and (5) improved enforcement and compliance assurance through increased sensitivity to potential environmental justice problems in rule-making (Bullard, 1993; United Church of Christ Commission for Racial Justice, 1992). The third solution is of course integral to the nature of this study, and is a strong rationale for its conduct.

The National Environmental Justice Advisory Council (NEJAC), and advisory council to the EPA, recently spoke of systemic reform of the norms for democratic involvement decisionmaking. The new grassroots movement for "environmental justice," the report noted, "represents a new vision borne out of community-driven process whose essential core is a transformative public communication and exchange of information that are vital to communities " (Waste and Facility Subcommittee, 1996). At the core of this vision is an elaboration of the terms for an "informed and empowered community involvement” in the decisions affecting a community's overall well being (Waste and Facility Subcommittee, 1996).

Generally, advocates for public participation identify at least four conditions that make possible a more substantive model of citizen involvement in environmental issues. The conditions include the right to know, the right to participation, the right for independent expertise, and the right to act.

\section{Role of the Mass Media}

In modern America, the role of mass media, in addition to providing entertainment, is to inform citizens to enable them to make intelligent decisions. The information provided by the mass media uses various outlets including film, broadcasting, and newspapers. The information provided by the mass media is then used by individuals and by groups or large organizations to understand the patterns of health levels within populations and then the linking of illness to major local environmental factors or events. The information exchange results in challenges to hazardous sites and unwanted land-use and location conflicts involving unwanted land uses.

Environmental justice activities enable small grassroots organizations to bring national attention to environmental disasters that are intentionally located in areas populated by people of color and people with low social and economic status. Activists generally are average people driven by necessity to resist and change a system they believe is betraying them. They watch as the fabric of their lives is frayed by the danger of pollution and the effects chemical industries have on their children and grandchildren. They write letters, attend meetings, organize protests, interact with politicians and bureaucrats, and devote most of their personal time to the movement (Bullard, 1993).

The subject of environmental justice has become a concern with a growing audience, most notably in the mass media market. Two docudramas, "A Civil Action" (1999) and "Erin Brockovich" (2000) focused on real-life individuals fighting for information concerning the health of their communities. "A Civil Action" traces the formulation and outcome of the legal complaints filed by eight families in East Woburn, Massachusetts, against three local industries for the improper handling and disposal of toxic chemicals (Harr, 1996). The docudrama "Erin Brockovich" centers on a struggling single mother who helps California plaintiffs win a \$333 million settlement of water-contamination claims against Pacific Gas \& Electric Company (Grant, 1992). 
Cover stories in U.S. News and World Report (June 19, 2000) and Time (Special Edition, Spring, 2000) profiled individuals and organizations and their efforts to pin-point the sources of deadly environmental wastelands. The cover stories focused on two of the most notable environmental disasters in the United States - dioxin and polycholorinated biphenyls (PCB) poisoning of the community of Love Canal, New York, and the PCB contamination of Anniston, Alabama.

The other cover story focused on Anniston, Alabama, a small, rural, poor and predominately black area. The community's neighbor since the 1930s was a Monsanto chemical plant that makes industrial and pharmaceutical chemicals. Similar to the Love Canal incident, PCB was released into the soil (The Center for Public Integrity, 1996).

The community knew it was up against a giant corporation with annual revenue of $\$ 69$ billion, but Anniston residents were determined to take a stand based on what was best for the health and welfare of the community. In early 1980, local citizens filed a multimillion dollar class-action lawsuit against Monsanto. Mary McCastle, a 72-year-old grandmother, lead the battle against Monsanto:

"We had no warning, no information about Monsanto. We didn't know what they were dumping. We did know it was making us sick. People used to have nice gardens and fruit trees. When Monsanto came in all our gardens died. Some days the odors from the plant would be nearly unbearable” (1988).

The suit was settled out of court in 1987 and the plant stopped producing in 1988 when the Environmental Protection Agency (EPA) banned any production of PCB or any by-product of PCB (Agency for Toxic Substances and Disease Registry, 1988). The soil and water of the community remain contaminated with the chemical that continues to poison the environment, resulting in the deterioration of health levels in the community. PCB has long been linked to life-threatening diseases including various forms of cancer, diminishing IQ levels, poor memory, and lack of coordination in Anniston residents (Agency for Toxic Substances and Disease Registry, 1988).

Opponents accuse these activists of exaggerating health threats from pollution and standing in the way of progress. By 1988, after 18 years, the Occupational Safety and Health Administration (OSHA) had managed to set limits on only 25 of the thousands of chemicals in the American work force, and only after lengthy, stop-and-go lawsuits on each. In 1989, when OSHA tried to set standards for an additional 200 chemicals identified as harmful through well-established research, the courts struck down the agency's directive (Fagin \& Lavelle, 1996).

America witnessed the unfolding of two interpretations of Environmentalism: a media-framed, technically oriented, behavior-defined set of national issues and individual activities; and a less visible more contentious grouping of rooted movements, networks and actions (LeMay, 1991). Media portrayal of environmental issues were limited to recycling, conserving water or energy, and making more "environmentally sensitive purchasing decisions" (Gottlieb, 1991). Environmental activity, including pollution prevention, industrial restructuring, community right-to-know and environmental equity, became additional forms of consumption (Gottleib, 1991).

Although environmental justice is a term with which Americans are only now becoming familiar, we can see its development over the years beginning with the writings of Rachel Carson in the 1960s, then progressing into main stream media. Now environmental justice is, albeit small and controversial, a part of the environmental standards in the United States.

\section{Significance of the Study}

This examination strives to provide understanding of information needs and information dissemination practices of a single community in its encounter with a corporate employer over environmental and economic development issues. The community of Perry, Florida thus serves as a 
model of a small town struggling for environmental fairness and equity. Its local environmental advocacy group, Help Our Polluted Environment (HOPE) is much like others in this country who have waged similar battles, and represents the American grassroots organizations that have become increasingly vocal and active. HOPE's effort to combat environmental inequity is representative of a significant element in America public policy. Studies of utilization of information of these groups fall short in examining the manner in which information-based decision-making embraces the community and/or neighborhood.

One of the shortcomings in the available literature is that most of the reported studies of environmental justice have characterized disparities only in terms of proximity to potential sources of exposure or, in a few cases, to measured exposures and have not taken the next step of trying to characterize or compare either the incidence of exposure or differences in health status between these populations and the general population (Bullard, 1987a; Glickman \& Hersh, 1995; Greenburg, 1993, United Church of Christ Commission for Racial Justice, 1987; U.S. General Accounting Office, 1983, Zimmerman, 1993). Few studies have looked directly at whether local, residential exposure to environmental agents is associated with an increased incidence of disease.

This study is written from the perspective of environmentalist orientation and therefore utilizes the theory and philosophy of those seeking environmental justice. While environmental justice advocates attempt to open doors of discourse they face significant obstacles. Environmental activists confront a policy regime that is more than simply stacked against them. Katz and Miller (1996) argue that public policy making employs a "closed communication of authority, control, precision associated with the power of science and technology and the cultural belief that these are the only valid ways of knowing and doing," leaving few assurances that the public will ever become informed or empowered to participate in meaningful dialogue with decision-makers (Katz \& Miller, 1996).

The Model Plan for Public Participation reported at a minimum, the public participation process must provide stakeholders with the information that they need to participate in meaningful ways. This requires news information and education strategies that are sensitive to a community's needs and which are geared toward community capacity building (MPPP, 1996). As Shannon (1991) explained, decision-building "involves both stakeholders and agency staff in creating knowledge and developing shared commitment toward a mutually defined course of action" (Shannon, 1991).

On one side, officials and consultants speak in scientific terms of chemical substances; on the other side, community groups and leaders feel their concerns matter little and there efforts to gain understandable information fail.

In this day of global information including, but not limited to, the Internet, information exchange has not really changed much from the days of Socrates (470-399 B.C.). Information was documented and transcribed by philosophers and others of the ruling class. Working people were generally illiterate, creating an information gap between, what is known as today, the haves and have-nots. The information gap, in the context of environmental justice, is linked directly to the information "haves" and "have-nots".

In recent years, researchers have pointed out that there are huge differences in people's ability to obtain and act on information. This is causing concern, with experts arguing that a fundamental split is developing between the information haves and have-nots throughout the world. The information rich have good access to information-especially online, but also through more traditional media such as newspapers, radio, television, and books-and can plan their lives and react to changes in circumstances on the basis of what they know or can find out. The information poor don't have such access and are vulnerable to all kinds of pressures. Though the information rich are mainly in the industrialized countries and the information poor are mostly in the developing 
world, similar splits are obvious between prosperous and disadvantaged groups inside industrialized countries.

The subject of environmental justice elicits strong emotion from many parties. Neither the serious health concerns nor the charges of biased on unfair policies that are implicit in the subject can be taken lightly. An extensive body of literature documents the fact that not all segments of the U.S. population have experienced the same advances in health status and gains in life expectancy (National Research Council, 1998).

\title{
The History Of The Environmental Movement
}

\author{
"Equal Justice Came Out of Community Involvement" \\ Vernice Miller-Travis, Program Officer of Community \\ Development, Ford Foundation \\ (Florida A\&M University, April, 1999).
}

The impetus, motivation, and stimulus of the environmental justice movement has been to ensure that all communities are safe and healthful environments (Executive Order, 12898), however, citizens have found it difficult to participate in policy-making on issues that have direct impact on their health and safety, their environment, and their future generations. The citizens have had limited ability to gain access to information concerning these issues affecting their lives and their communities. Citizens affected by environmental inequities generally face several barriers related to low level literacy and educational levels, high unemployment, and low-income distribution (Hill, 2000).

Minorities disadvantaged in terms of education, income and occupation in the United States bear a disproportionate environmental risk (Bullard, 1993). Understandably, socio-economically deprived groups are more likely than affluent whites to live near polluting facilities, eat contaminated fish and be employed at risky occupations (Gould, 1986). Because minorities are statistically more likely to be economically disadvantaged, many researchers assert that "environmental racism" or racial bias in imposing environmental threats, is the central cause of disparities in risks that minorities face (Calderon et al., 1993). Others have argued that race is an independent factor, not reducible to socioeconomic status, in predicting the distribution of air pollution, contaminated fish consumption, municipal landfills and incinerators, abandoned toxic waste dumps and lead poisoning in children (Bullard, 1993).

Regardless, it is clear that the influential majority composed of those citizens who comprise the middle class, is not affected by environmental injustice in such direct manner. Both race and socioeconomic status appear to be major factors when assessing these outcomes. It should be noted that there is debate about their relationship to each other. Because they are more likely to be poor, minorities are also more likely to be politically disenfranchised. Thus, they are typically less able to fight unwanted risks. This disability could explain the disproportionate share of environmental threats that minorities appear to bear (United Church of Christ Commission on Racial Justice, 1987).

In these predominantly Black communities of lower socio-economic status, the initial grassroots organizing was carried out to protest against landfills, incinerators, toxic waste, chemical industries, salvage yards, and garbage dumps. Strategies included demonstrations, public hearings, lawsuits, the election of supporters to state and local offices, meetings with company representatives, and other approaches designed to bring public awareness and accountability (Bullard, 1990).

In examining the history of the environmental movement in the United States, It is important to recognize that a "veil" exists with respect to explaining the historical perspectives of socially 
marginalized communities who have experienced environmental inequalities. Sylvia Hood Washington of Case Western Reserve University, issued a report in 1997 that attempted to reveal the nature of that veil so that readers could see as well as hear the environmental history of communities from the perspective of those who have been environmentally disenfranchised. This history included her own struggles as an African-American who grew up in a segregated Black community that suffered and fought against unfair environmental policies for almost 50 years in Cleveland, Ohio. It also included a comparative history of "white" immigrant and migrant communities who lived around the Chicago Stock Yards who suffered from what she called "environmental ethnocentrism"; the twin of environmental racism. The final report depicted the rich history of environmental activism and advocacy in working class and socially marginalized communities (Washington, 1997).

As noted, the term environmental justice is just becoming familiar. It is an unfortunate reality of life in America that government policy often affects some ethnic groups more than others (Environmental Law Reporter, SARA, 1986). This chilling but hardly surprising revelation can be likened to the discovered inequality among animal species in George Orwell's 1945 publication of Animal Farm. Dr. Robert Bullard, a member of President Clinton's Administration environmental transition team, revealed statistical data, that if not alarming are, indeed, disappointing in a country founded on egalitarian principles. He found a strong correlation between race and class and polluted environment and the effects on individual standards of living (Bullard, 1995).

In 1983, a study by the U.S. General Accounting Office, observed a strong relationship between the siting of offsite hazardous-waste landfills and race and socioeconomic status of surrounding communities. It identified four offsite hazardous-waste landfills in the eight states that compose EPA's Region IV (i.e., Alabama, Florida, Georgia, Kentucky, Mississippi, North Carolina, South Carolina, and Tennessee). The data detailed the socio-demographic characteristics of the communities where the four hazardous-waste landfill sites were located. Race and class appear to be the major factors associated with communities in proximity to toxic centers. Findings such as these serve to place the struggle for environmental justice among the most important health challenges of our nation at a time when the challenges to the health establishment in terms of disease control and prevention are mounting. Bullard was able to point out that minority and low-income neighborhoods had been the toxic "dumping grounds" for the nation and the world (Bullard, 1995). Again, this may not be entirely surprising, but nonetheless is disconcerting.

To become classified as an environmental justice community, a community must be: comprised of minority or low-income groups; who are excluded from those who set policy or make decisions on the environment.

In an interview with Dr. Robert Bullard, one of the pioneering scholars and activists in the environmental justice movement, I asked him what is environmental justice?”

"The environmental justice movement has basically redefined what environmentalism is all about. It basically says that the environment is everything: where we live, work, play, go to school, as well as the physical and natural world. And so we can't separate the physical environment from the cultural environment. We have to talk about making sure that justice is integrated throughout all of the stuff that we do. What the environmental justice movement is about is trying to address all of the inequities that result from human settlement, industrial facility siting and industrial development. What we've tried to do over the last twenty years is educate and assist groups in organizing and mobilizing, empowering themselves to take charge of their lives, their community and their surroundings. It's more of a concept of trying to address power imbalances, lack of political enfranchisement, and to redirect resources so that we can create some healthy, livable and sustainable types of models” (1992). 
William Falk and Thomas Lyson described the uneven economic development and plight of rural southerners in their book High tech, Low tech, No tech. The authors wrote:

"Not all citizens have benefited from the upturn in the southern economy. In fact, many may not have benefited at all. Blacks, women, and people living in rural areas have, in varying degrees, received little or none of the job opportunities and economic affluence that has washed over the region. The quality of life and opportunity for improvement for these people left behind have remained essentially unchanged over the last fifty years” (1988).

Bullard points to the convergence of environmental and social justice. People of color and people with low social and economic status are now beginning to understand that environmental justice is a social justice issue (Bryant \& Mohai, 1992; Bullard, 1990; United Church of Christ Commission for Racial Justice, 1992).

Environmental justice addresses social justice related to human activities that affect both human and natural environments, including the impact of human activities upon human health and values, immediate living and working conditions, natural resources that humans depend upon, cultural values intimately tied with the natural environment, and ways in which the institution of environmentalism affects human relations. This description reveals that social problems are intimately connected with environmental problems and may point in either direction: the social problem may be the cause of the environmental problem or the reverse may be true with the polluted neighborhood being the causal element for subsequent societal isolation and cultural lag (Figueroa, Debating the Paradigms of Justice: The Bivalence of Environmental Justice, 1999).

Social justice, political empowerment, equal education, fair employment practices, and open housing have been major goals of social justice advocates. These factors have different impact for different individuals. It is one thing to advocate "saving trees" and a totally different situation when confronted with "saving jobs for the social disadvantaged" (Bullard, 1987). Unemployment and poverty have been individual social issues different than those concerns voiced by middleclass environmentalists. This points to the dilemma that exists in providing impetus for governmental remediation.

Activists are faced with various obstacles, not just related to the economic backlash of closing a polluter:

“. . government officials and agencies have exercised their power to exploit the less politically influential, the less informed and the poorer members of society. Rather than receiving protection from a democratic system designed to protect the minority voice, the ethnic and racial minority communities became a convenient scapegoat for difficult political decisions” (Colquette \& Robertson, 1991).

The environmental justice movement is comprised largely of small, democratically run grassroots groups. Many of the groups may or may not have environment in their names. Nevertheless, they are truly environmental groups that are grounded in the community. It is also important to note that the vast majority of the grassroots groups are led by women, minorities and the Black community-a significant deviation from the leadership of national environmental groups (Chavis, 1987).

In The New Environmentalism, Mark Dowie analyzes the growth of grassroots community organizations that are emerging around the country to demand participation in environmental decision making. He points out that the large mainstream environmental organizations have failed to attract minorities and the poor. Grassroots activists perceive these organizations to be arrogant and elitist, more concerned with wilderness, wildlife, and natural resource conservation than with the environmental damage to low income communities around the country (Dowie,1992). 
Dowie urges the American environmental movement to develop into “. . . a broad-based, multiethnic movement that takes a long term global view, challenges prevailing economic assumptions, promotes environmental protection as an extension of human rights, and engages in direct action when necessary. If it pursues this goal, the movement can forge a new society” (1992).

Blacks were generally absent from the mainstream environmental movement. The primary activism against environmental injustice emerged from mainstream environmental organizations, including the Serria Club and Greenpeace. Examples include protests, demonstrations, lobbying, and lawsuits against nationally recognized companies including Procter \& Gamble (Gaugh, 1991).

Citizen-participation programs were the result of a variety of factors that converged in the late 1960s. Innovative representational strategies were developed within agencies at many levels. They include new environmental protection agencies at federal and state levels. In addition, older regulatory and public works agencies such as the Federal Trade Commission and the Army Corps of Engineers, as well as health planning agencies and a host of others in virtually every area of administration and at every level of government, have been pushed to include more access to the public at large (Hoberg, 1992; Melnick, 1983; Stewart, 1975).

Under Presidents Nixon and Ford, however, the 1967 Air Quality Act had little effect. The Office of Public Affairs at EPA, always under-funded and with little money at its disposal, was in charge of enforcing the Air Act. It was headed by public relations people with clear political agendas heading the agency (Dahl, 1970; 1989). Under President Carter, support and funding increased for citizen participation and the Consumer Protection Agency was created to right certain wrongs (Pertschuk, 1982).

The agency had little bite, however, and had limited impact on local environmental issues. Support and funding was dramatically cut under President Reagan's terms forcing many in the agency to resign (Berry, 1981). President Clinton's EPA office reopened the door for citizen participation by offering state and local seminars and training. Under the current administration of President George W. Bush, the vision of civic environmentalism has been discussed within various offices at the EPA, but the resolve to continue to serve the public at-large with the streamlining of the government may be in conflict with an activist stance on the part of government.

Long before the Environmental Protection Agency (EPA) was able to set in place the enormously complex technical and administrative procedures for tracking, managing, and disposing of hazardous wastes, the dramatic and widely publicized revelations of toxic exposure to the community in Love Canal, New York, appeared in the national media in the summer of 1978 (Hadden, 1989). This bellwether event marked the emergence of cooperative activity among fighters for the environment. The Citizens' Clearinghouse on Hazardous Waste (CCHW) movement soon began to forge links between the workplace and residential community in its campaign for "right-to-know" laws at the State and eventually the federal level (Gibbs, 1990; Hadden, 1989).

Communities around the country with similar environmental problems began organizing into grassroots community groups. The groups connected and networked and by 1982 a social movement had emerged. Today, the grassroots movement for environmental justice is made up of roughly 5,000 community groups nationwide. Women play a dominant role in the movement as the major leaders and organizers of the community groups. (Gibbs, 1988)

On July 1, 2002, President George W. Bush stopped Superfund monies to 33 sites in 18 states, including five in Florida. By doing so, the clean-up cost shifted to the taxpayers and not the polluter (EPA Inspector General’s Report, 1 July, 2002).

Grassroots groups sprang up in increasing numbers, especially in communities that were being considered for the placement of hazardous waste treatment facilities, or where contaminated 
dump sites were discovered (Gibbs, 1999). The most vital element in the rise of environmental justice movement was the emergence of grassroots activists willing to lay everything they have on the line. Over the course of the 1980s, perhaps as many as 10,000 local groups, including many in poor and minority communities, had contacted or affiliated with one of the two major networks in the toxins movement. The Citizens Clearinghouse on Hazardous Waste (CCHW), founded by Love Canal homemaker Lois Gibbs in 1983 and the National Toxins Campaign (NTC) was founded by community organizer and asbestos survivor John O’Connor in 1984.

The practice of toxic-waste disposal has generated demonstrations in many communities across the country, with the first national protest on the hazardous-waste issue being held in 1982. Demonstrations and protests were triggered after Warren County, North Carolina, which is mostly low-income and black, was selected as a landfill site for more than 32,000 cubic yards of soil contaminated with highly toxic PCBs (polychlorinated biphenyls) (Pollack \& Grozuczak, 1984). The soil had been illegally dumped along the roadways in fourteen North Carolina counties in 1978, and had been collected for ultimate disposal (Bullard, 1993). As executive director of the "United Church of Christ's Commission for Racial Justice," Charles Cobb spearheaded the effort to document "environmental racism"- some of which was itself the by-product of more stringent regulation, information dispersion, and the empowerment of some communities to resist toxic dumping more effectively than others (Hadden, 1993).

Although the demonstrations in North Carolina were not successful in halting the landfill construction, the protests brought a sharper focus to the convergence of civil rights and environmental rights and mobilized a nationally broad-based group to protest these inequities. These early events led to the increased growth of environmental grassroots organizations. Grassroots organizations across the country began to network by exchanging information and ideas. They emphasized community empowerment through legislative lobbying and judicial appeals, and vocalized their concerns to the threat of the health and well-being of their neighborhoods (Hadden, 1989).

Various community struggles with environmental issues in the 1980s gained the bulk of the initial national attention at the time, and the campaign against environmental injustice continues today. As pointed out, there is a growing body of evidence revealing that people of color and low economic means are subjected to a disproportionately large number of health and environmental risks in their neighborhoods (e.g., childhood lead poisoning); and on their jobs (e.g., pesticide poisoning of farm workers) (Bullard, 1993; Byrant \& Mohai, 1992). The effects of pollution and environmental hazards on people of color, the poor, and the working class have been overlooked by environmental policy makers because it was perceived that those communities were politically powerless and would not protest and could not influence the site selection of such facilities. It was perceived that lines of communication did not exist or would not be utilized. Currently, the nation is confronted with a garbage and hazardous waste crisis with mounting nuclear and toxic wastes from its weapons and military installations.

Citizens who are tired of being subjected to the dangers of pollution in their communities have been confronting the power structures through organized protests, legal actions, marches, civil disobedience, and other activities. Information and its dissemination has been largely responsible for the increased activism. Community newsletters, pamphlets, magazines, classes, lectures, and videotapes have made it possible to recruit large numbers of people (Kuzmiak, 1991). When citizens in the contaminated communities are adequately informed about the hazards, their level of awareness and opposition to the toxic facilities results in active protest (Booth \& Jacobs, 1990; Caron, 1989; Mohai, 1990; Noe \& Snow, 1989; Ostheimer \& Ritt, 1976).

It was when these informational practices spurred the attention of local and national media, that publicity given to demonstrations and other resistance measures was maximized and the grass- 
roots movement became a familiar concept in the environmental justice movement. The information provided by the media sparked a nationwide growth in the environmental justice movement. Protests became an essential ingredient of an effective strategy for managing toxins, and the causes of these protests became well-known to the public. Activists used lawsuits, red-tape generating complaints, scientific studies, sit-ins, and picket lines to place pressure on corporations to make information available to citizens about the potential of hazardous waste and the dangers of toxic sites to the health of the community (Mazmanian \& Morell, 1992). It is easily seen that parallels can be drawn to the publicized activity for the earlier struggle concerning civil rights of minorities.

It is important to explore how people became powerless as the corporations became powerful. "We have to figure out how to speak honestly and act collectively to rebuild our democracy" movement from the old conservative "enviros." According to Connie Tucker of the Southern Organizing Committee, conservative or mainstream environmentalists such as the Sierra Club, "do not see democracy as an important issue-perhaps because to do so implies a direct challenge to corporate influence over our media, our elections, our courts, our schools, and our legislatures" (1995). For example, the Environmental Defense Fund (EDF) has refused to endorse campaign finance reform to get the corrupting influence of private money out of our elections. The grassroots movement, on the other hand, believes democracy is the fundamental environmental issue. "Without democracy there can be no justice, and without justice there is no way to protect human health or the environment” (Tucker, 1995).

Public participation includes a broad range of communicative practices and information exchange aimed at voicing public opinion, influencing decision-making, and/or shaping environmental policy. Such practices are undertaken by a variety of individuals and groups, including elected officials, government agencies, scientific and technical experts, citizens, activists, academics, social movement organizations, corporations, public relations firms, and policy research institutes (Environmental Communication and the Environment, 1999). Their opponents have accused them of exaggerating health threats from pollution and standing in the way of progress. As previously stated, the activists' efforts often fall short of their goals, and many of them have been personally attacked for their activism.

"I believe we can win democracy back because I have experienced it myself," says Gibbs. "Most people, if you ask them if they could attract the attention of the president of the United States, they would say 'no'. But Love Canal is a shining example of how a small group of blue-collar workers, by luck or by chance, became very sophisticated in effecting change in the political process and in getting the president to come to their backyard and to give them what was right" (1999).

Sadly, in spite of President Carter's admonition, a need for environmental justice continues to create activists. In Pensacola, Florida, Margaret Williams heads Citizens Against Toxic Exposure, a group formed in 1991 to battle the Environmental Protection Agency's digging on a toxic site near her home. "As with most people, environmental issues had never crossed my mind," she says. But when residents-most of them elderly and not well off financially-began suffering eye and skin irritations and breathing problems, Williams quickly learned about the poisonous effects of dioxin. Although her group lost the battle to stop the digging, it recently was successful in persuading the federal government to pay for relocation of all 358 families (Williams, 1999).

Williams, like Gibbs, is a grassroots pressure lobbyist who utilized the available information channels to make known the plight of her neighborhood. Closer to Perry geographically is the situation involving the Escambia Treating Company (ETC) Superfund site, located in a mixed industrial and residential area in north central Pensacola, Florida. It has been reported that the 
poisonous chemicals released from the site may have been responsible for more than 40 deaths due to cancer (CATE Report, 1985).

The U.S. Environmental Protection Agency (EPA) data confirms that dangerous levels of dioxins had migrated into some residents' yards. The location of the site, at an elevation of more than 60 feet above much of downtown Pensacola, along with conditions present during the plant's operation suggest that storm water runoff often carried contaminants well beyond the closest residential neighborhoods.

Mrs. Williams took her campaign on the road to EPA's National Environmental Justice Advisory Council or NEJAC in 1985. She got NEJAC's Waste Subcommittee to hold a Superfund Relocation Roundtable in Pensacola. She won the backing of more than 100 grassroots organizations. Citizens Against Toxic Exposure (CATE) began to get media coverage in the U.S. and in the foreign press. The Pensacola story became the "Black Love Canal.” It was just a matter of time until EPA had to give in and take steps to correct the condition. The EPA nominated the Escambia Wood Treating Superfund site as the country's pilot program to help the agency develop a nationally consistent relocation policy that would consider not only toxic levels but also welfare issues such as property values, quality of life, health and safety. This was a monumental achievement and came about through pressure exerted by an influential and informed population.

One such informational event came about In 1996, when President Clinton was campaigning for re-election to the presidency in Pensacola, Florida. At that time, CATE was fighting to have their families evacuated from a toxic area, and with the help of donations that CHHW helped to raise, CATE bought a full-page ad in the Florida edition of USA Today for $\$ 7,000$. The President's campaign staff became informed at that time. Gibbs said, "They were pleading with the president and on October 3, 1996, the families were given the go ahead for relocation.” American people have been speaking out. We want to regain democracy; we just need to get a whole lot smarter about how we do it" (Gibbs, 1996).

Information exchange is the key to citizen involvement in environmental policies. In the most basic terms it is simply people working together, providing opportunity for face-to-face dialogue among contending parties. With a combination of such civic dialogue, and the inclusion of good science, and logical discourse through open meetings, public participation is abetted by the information process. It requires that all interested parties-individuals, groups, and formal organizations operate in good faith with a real desire to reach a fair and equitable agreement. (Friedmann, 1987)

In summary, this section has supplied a brief overview of the impact small grassroots organizations have had on the environmental justice movement. Personal experiences demonstrate the human impact of an environmental disaster, the impact on right-to-know laws, and linkages to other environmental justice movements and environmental activists. There has been a notable effect on federal and state environmental laws. If laws, both federal and state, are to be changed, the process of information exchange among all of the parties involved must overcome barriers of human perceptions, expectations, and values (Caldwell, 1993). Problems are resolved by the sharing of information and power and the selfless promotion of social, community, and economic good.

\section{The History of the Lumber Industry in Taylor County, Florida and HOPE}

Taylor County, Florida, has a colorful past rooted in the forest industry. Taylor County, named after General John Taylor in 1846, is located in the northern section of the state of Florida. The town of Perry, the county seat, is located in the center of the county, 50 miles southeast of Talla- 
hassee and 135 miles west of Jacksonville. Forests cover 90 percent of Taylor County, making the lumber industry its main employer. The county's first census, taken in 1860, recorded 1,384 residents. In the next century, the census showed only 99 additional residents (Perry-Taylor County Chamber of Commerce, 1995). Taylor County and Perry have grown, the population now stands as 7,502. However, even with this growth, Perry remains as a small, rural, farming and low-income community.

The lumber industry and the Southern Railway System put Taylor County and Perry on the map. James Howard Stephens founded the first lumber industry in the area in 1842. The mill produced pencils from cedar. Teams of oxen pulled the cedar to a stream that leads to the open waters of the Gulf of Mexico. The cedar was cut into pencil stock, resulting in 1,157,000 miles of lead pencils annually. By 1890, the cedar forests were exhausted and the evolution of the timber industry in Taylor County was underway with the addition of two more mills: Brooks-Scanlon Corporation for yellow pine and the Burton Swatz for the raw production of cut red cypress (Nature Coastlines, 1999).

The introduction of the railroad to Florida made the timber industry of Taylor County a multibillion dollar business. In 1902, the South Georgia Railway first entered Perry. The railway made its way through the wilderness, once accessible only by foot or horseback, to supply needed raw lumber materials to the growing South Florida.

From the onset, the forest industry became a main topic of debate. As indicated earlier, the forest industry drew national attention to Taylor County. In order to accomplish this growth the industry drew on an untapped labor source-prisoners. On August 10, 1921, the county commission voted to lease prisoners to the Putnam Lumber Company with full support of the Florida Legislature. One House Member remarked, "Lumber companies are anxious to get prison labor and for a very good reason-the fact that free labor can't be hired for love or money to do the work the convicts are forced to do" (McCory, 1923).

To attract business investment and revitalize the local economy after World War II, (24952 Fla. Stat. No.1338), In 1947, the city fathers of Perry, Florida, and Procter \& Gamble asked the Legislature to designate the Fenholloway River for industrial usage, hoping to lure jobs to rural Taylor County. Local politicians, envisioning jobs and capital, pronounced this a fine idea.Lobbyists went to work. The bill they offered the Legislature designated the Fenholloway an "industrial river.

"Any manufacturing or industrial plant in Taylor County", the bill read, "is hereby empowered to discharge and deposit sewage, industrial and chemical wastes and effluents, or any of them, into the waters of the Fenholloway River and the waters of the Gulf of Mexico into which said river flows" (Laws of Florida, Chapter 24952-No. 1338, 1947). The House passed it April 22, 1947, the Senate the next day. Votes in both chambers were unanimous.

The bill allowed the mill to dump any waste, including industrial and chemical sewage, into the river. Procter \& Gamble/Buckeye Public Relations Manager, Dan Simmons, said it was a different time for America and industry had the upper-hand:

"The company came in and took advantage of the situation and back then the people weren't as conscious of the need to improve the environment. Senator Leroy Collins voted for the plant. It is hard to go back and vilify him for doing what they thought was right. It was after World War II, people needed jobs, the economy had to be rebuilt. Well here is-a good industry and high paying jobs. They knew it was going to impact the river and that is why they passed the law, so they could legally impact the river” (Simmons, 1999).

The Fenholloway River was now classified as an Industrial Class V river. Rivers are ranked as recreational or industrial and by Classes -- I to V, with the highest number belonging to non- 
navigational (for recreational) or for the support of navigation of barges or ships and industrial waste. An industrial class V river, is defined by the National Pollutant Discharge Elimination System, as is a body of water with the least stringent water quality standards and is only required to be maintained at a level sufficient to support navigation, utility and industry uses. An example of an industrial class $\mathrm{V}$ river is the Mississippi River and an example of a recreational class $\mathrm{V}$ river would be the Snake River in Wyoming.

The Fenholloway River was now legally designated as an industrial use river to help attract industry to the region. The bill allowed the mill to dump any waste, including industrial and chemical sewage into the river. The agreement is a classic example of "environmental blackmail." That is, if a state or community will allow an organization to build an environmentally unfriendly plant or dump, and pollute the air, water and land as it pleases, the organization will provide jobs. The paper mill located near Perry has been the industrial lifeblood of this otherwise rural region, an hour's drive southeast of Tallahassee near Florida's Big Bend.

Paper and pulp mills settled in Florida in the 1940s and 1950s. Including the paper mill in Perry after the state declared the Fenholloway River an industrial river . "The South, in general, was attractive to the worst types of industries. Florida was associated with the blighted South," said Gary Mormino, a history professor at the University of South Florida in Tampa. "Florida may have been better off not getting them." Few Gulf Coast residents were concerned about the toxins that industries were discharging - until it was too late.

"It was out of sight, out of mind," said Sarah Paris, an 82-year-old fifth-generation resident of the Perry, Florida area. "Oh my gosh, it was a way of life. We just took things for granted until we woke up and said, 'What's happening to my back yard?" "We are living with what was left to us by our forefathers," said Joy Towles.

By 1997 the company employed more than 800 Taylor County residents with three-quarters of those workers being Perry residents. The earnings in 1997 from all industries in the county reached $\$ 187,689,000$. Income from the Buckeye Cellulose Plant earned nearly $\$ 80,000,000$, nearly half of the total earnings of the entire county. The company had a $\$ 40$ million payroll and paid half the property taxes in the town of Perry and an estimated additional 1,000 jobs, including loggers, suppliers and other allied services, were produced indirectly from the mill. As of 1999, the largest employer in the county was the P\&G/Buckeye Cellulose Plant (formerly the Procter \& Gamble Pulp Plant) located in Perry. The plant in Taylor County ranks eighth in the state for toxic releases totaling 2,010,024 pounds a day into the air, water and land (EPA, 1999).

\section{The Product and the By-Product}

In 1954, P\&G mill began producing pulp. The process converts pine logs into cellulose, which is used in disposable diapers, plastics, rayons, explosives, film and even sausage casings (NPDES Permit No. FL0000876, United States Environmental Protection Agency). The P\&G/Buckeye Plant uses 2.4 million tons of pine trees annually. The process of making cellulose pulp goes on 24 hours a day, 7 days a week. It starts with trees - lots of trees. From there, the trees are cut into chips and turned into pulp, after soaking in strong chemicals. The goal is to separate the cellulose - a naturally occurring substance in cell walls of plants - from the rest of the tree.

The pulp gets washed, bleached to a more acceptable color and into a more purified state and then dried. Among the variety of pulp and paper products, Buckeye's pulp is considered the purest because it's used in specialized niche markets (Simmons, 1999).

The plant caused immediate environmental problems beginning with clear-cutting large tracts of trees. Hardwoods were demolished and replaced with pines, destroying the groves where animals 
and birds nested. The bigger problem, however, was the river. Fifty-million gallons of the plant's discharge began flowing into the Fenholloway River (Environmental Protection Agency, 1990).

The unlimited and uncontrolled dumping made the Fenholloway River the worst polluted river in Florida and the $30^{\text {th }}$ worst in the nation. The main pollutant is "dioxin"-a general term to describe a family of 75 different compounds with widely varying degrees of toxicity. Dioxin is the main ingredient of Agent Orange, the compound used during the Vietnam Conflict that killed hundreds of thousands of Vietnamese and caused illness and death to American soldiers as well (Environmental Law Reporter, 1989).

Between 1990 and 1994, 12.1 million pounds of toxic chemicals were discharged into Florida water-ways, while another 58 million pounds of toxins were flushed into the state's sewagetreatment plants, giving Florida the No. 11 spot in that category. The problem, according to the environmental groups that compiled the figures, is that most producers of toxic wastewater are exempt from having to report their releases, said Susie Caplowe of the Florida Consumer Action Network (Environmental Working Group. Compiled from U.S. Environmental Protection Agency, Toxics Release Inventory 1990-1994).

From 1990 to 1994 using figures given to the federal Environmental Protection Agency by the manufacturers themselves, as part of the Toxic Release Inventory program, the Fenholloway River ranked second in dioxin-chemical releases. Among the most polluted rivers in the state, according to the study, are the Fenholloway River in Taylor County and the Suwannee River near Live Oak. Also, the Buckeye Florida plant near Perry is among polluters reporting the greatest amounts of toxic chemicals discharged into Florida waters (EPA, Toxic Release Inventory. September, 25, 1996).

The National Academy of Science Institute of Medicine links a wide range of health problems to exposure of dioxin: soft tissue sarcoma, Hodgkin's disease, non-Hodgkin's lymphoma and liver disorders. The Academy also has evidence of its association to other cancers: respiratory, prostrate and multiple myeloma (Capek, 1993). The health risks of dioxin do not stop with cancers. Even at low levels of exposure, the Environmental Protection Agency (EPA) identifies other serious ailments: damage to the body's immune system, neurological and reproductive systems (Citizen's Clearinghouse for Hazardous Waste, 1993).

It wasn't until 1990 that the Environmental Protection Agency had documented severe chemical pollution in the Fenholloway, with apparent heavy impact on fish. Epidemiologists found high rates of leukemia and other illnesses associated with chemical pollution among the nearby human population (Merritt, 1994). The 1990 Environmental Protection Agency study found that the Fenholloway River had dioxin levels 1,900 times greater than the agency's standard. Immediately following the 1990 EPA report, the Florida Department of Health and Rehabilitative Services, in conjunction with the Florida Department of Environmental Regulation, issued a press release announcing a health advisory relating to the Fenholloway River. This health advisory in part urged the public not to consume fish caught in the river because of dioxin contamination. In addition, Procter \& Gamble Cellulose Company, Buckeye's predecessor, posted signs at four locations along the river warning in the English language that the Fenholloway was classified as a Class V river and that it was "not designated for recreation or fishing".

Still, in 10 years, neither the state nor the federal government has posted signs along the Fenholloway to warn people not to eat the fish. "It's pitiful," said Joy Towles Cummings. "People are still eating contaminated fish, and nobody's doing anything about it. I mean, how long do we have to wait?" When asked why the Florida Department of Health hasn't put up more signs warning anglers of the dioxin in Fenholloway fish, state toxicologist Joe Sekerke didn't have an answer. "It hasn't been done, and I don't know exactly why," Sekerke said. "Putting signs up doesn't usually keep people from eating the fish anyway" (Phone interview: 02 September 2001). 
To be sure, isolated groups of citizens had voiced their concern about pollution from the Proctor \& Gamble plant in earlier years, but such efforts were relatively weak and unsuccessful. In a conversation with Sara Paris, one of the co-founders of HOPE, it was learned that "in the 1970s one group started up to try to do something about this problem (pollution), but it was just totally crushed. The local paper and local politicians pretty much crushed them. The company simply bought up their property and relocated them...their property was bought by the company. They physically relocated these people who complained back then” (Sara Paris, HOPE Co-Founder, 1999).

Paris went on to say that since that time not much had changed of the tactics that had been employed:

"We've been criticized in the local paper. They called us armed radical environmental terrorists. They have tried to run us down and really tried to make us out to be the bad guy in order to get the focus off of the problem. They've threatened our homes, our vehicles, and us traveling down the road (1999).

This brief interchange with a dedicated activist seeking to make her community a cleaner, healthier place to live places in perspective the immense task of disseminating vital information to the people when economic interests are threatened. It identifies an extreme social inequity when the forces of the media designed to keep citizens aware of harmful factors are linked to a political system that does not intervene because it is enjoined to the best interests of economic development. In proclaiming the "goodness" of such efforts, it is simple to place obstructionists in the role of troublemakers to the best interests of the community, thus providing the confusion necessary to retain power.

With the emergence of Project HOPE, however came a stronger, better organized voice through which information could be disseminated.

\section{The Protests Begin: The History of HOPE and Public Information}

In 1954, Procter and Gamble Cellulose Company built a pulp and paper mill in Perry on the same river, the Fenholloway. The plant immediately began discharging 50 million gallons per day of treated effluent, which on average constitutes $85 \%$ of the Fenholloway River's flow. By 1990, the status of local economic hero, $P \& G$, was being transformed into a national environmental outrage.

State officials conducted several well water tests in June 1990 but found "no conclusive evidence" of chemical compounds. Nonetheless residents were advised not to drink water from their wells by the Florida Department of Health and Rehabilitative Services in September of 1990. Water pollution in the Fenholloway River gained further attention in March 1991 when the Tallahassee Democrat published a Pulitzer prize-nominated story on the Fenholloway (Hauserman 1991). The article stimulated broad debate and encouraged environmental groups to petition the EPA to challenge Florida environmental officials and upgrade the river from its industrial classification to a recreational river where "fish can survive and people can swim" (Multinational Monitor 1991).

Perry resident, and self-made environmentalist, Joy Towles, became the mainstay of the fight for environmental justice and the major force for dissemination of information. She thus became the spokesperson for the residents and began an environmental justice movement against the billiondollar corporation $(\mathrm{P} \& \mathrm{G})$. The dispute between the two was over the release of dioxin into the environment, making drinking water unsafe and affecting the quality of life with respect to fishing, farming, and clean air. In studying the battle for environmental justice in Perry, Florida. 


\section{Communication Begins}

Towles began her task by contacting people who lived near the pulp plant to investigate stories of polluted water.

"I had written to the Tallahassee Democrat, I had begged them to do some articles about the Fenholloway, that was way back in '91. I'd written to 60 Minutes, I'd done everything I knew to do to draw some attention to this problem, 'cause (sic) I knew it was there. I knew it was happening and nothing was going on, and all of a sudden, after I had put an ad in our local paper asking people to join a class action suit on the water quality there, that came out in the local paper on a Friday and the very next Sunday, this article came out in the Tallahassee Democrat and I was jumping up and down and screamingsaying finally somebody noticed, good God somebody is finally noticing what's happening here and that started a whole lot of things to happen a little bit before that. I had met some people in Greenpeace and they promised to help and they have and then in '92 a state EPA report came out with this 'state links the dirty wells to the P\&G Mill” (1999).

The local ad in the Perry newspaper opened the door of information exchange, and found a ready audience. For the next few days, Towles said her phone rang off the hook with nearly 400 calls in 2 weeks (Towles, 1999).

"I was on the phone for over two weeks, I got over 500 phone calls. So, I knew there was a lot of concern here about the water. Lot of people would say:

"You know that I'm on your side, but I can't get give you my name. I can't get involved in this because my husband or my brother works at the mill. I don't know what could happen to me, they might burn down my house if I get involved with your group, but I'm on your side. Since people have called and said I can't get involved, but I really believe in what you're doing, so please don't stop. It's given us the dedication to go on. We've got over 300 members now, we've got about 30 really active members, who always come to the meetings and help out and who have really given a lot since we started" (Towles, 1999).

Many of those callers were former P\&G/Buckeye mill workers who had a story to tell and wanted an opportunity to provide first-hand information on what went on inside the plant and just where illegal discharges were located. Towles also connected with people who lived near the pulp plant to investigate stories of polluted water. Her investigations were met with mixed outcomes:

“The community didn’t want us investigating anything. For us (HOPE) to say anything, the economic value for the community would be lost. The only thing they're thinking about is the dollar bill. What they (the community) don't (sic) realize is that sure this mill provides jobs, benefits such as retirement, partial health benefits and so on and so forth. It's also their money that's paying for their insurance to treat a disease or an ailment that the company's effluent causes. The only thing they can see is the physical dollar" (Towles, 1999).

Obviously, this is a complaint that is not unexpected in situations such as this where threats to financial well-being are perceived to exist. With care and careful direction by Towles, the project was indeed supported by enough people so that Help Our Polluted Environment (HOPE), the organization dedicated to a toxic-free future came to life in 1989.

The messages from the phone calls appeared clear to Towles -- not only were members of HOPE concerned with the pollution, but also employees of the plant were concerned. Towles and other members of HOPE knew they had a long road ahead of them to fight for a cleaner and safer community and they also knew a wide array of information would have to be gathered and deci- 
mated. "We developed a list (of questions) and sent it out on the mailing list to anybody I thought would help us here. Anybody here that would help or anybody somewhere else that would help us...

"Well it's not quite as easy as we thought it would be. You got a community that needs the jobs. People that have invested their lives in the plant so its not as simple as we'll fix it or close it down tomorrow. What you actually do is you get the best resources that you can identify the best scientific people the best legal advice, you talk with the regulator, you talk with the stake holders and then you identify with a strategy to make improvements. You go as fast you can as far as you can that the resources will allow you to do that. So then when specific groups come in and say that we want you to eliminate the use of the element chlorine right now cause we are fixing to put a railroad blockade across your railroad track. You aren't going to get anymore in. Then you have to deal with that in the context of a larger theme. Try not to let it distract it away from your larger mission but at the same time be responsive to people who have legitimate concerns, because it may be some things that you can do. And we human beings continue to learn and you can never totally isolate a group and say we won't listen to that group because they might have part of the answer" (1999).

Ironically Towles had been working for a chemical company while she had been gone selling agriculture chemicals and she knew all too well of the problems with ground water contamination.

"People's wells were contaminated and I was very aware of how easy it was for a person's well out in the country to get terminated. I said does everybody know bout this. She said there are a lot of people that know bout it and people don't talk about it much. Well is anybody trying to do anything about it. She said oh no you don't say nothing bad about Buckeye around here and I said this is ridiculous and I got all fired up” (Towles, 1999).

The information activity began to work for Towles when she discovered through her network of insiders (e.g., workers at the cellulose plant) that P\&G/Buckeye had been "scurrying to keep water problems quiet” (Towles, 1999). Many landowners who complained about contaminated wells had been given offers to swap land with P\&G, while others had new wells drilled, courtesy of P\&G. "P\&G/Buckeye was also directly supplying bottled water to those who complained and offered free bottled water to anyone who wanted it" (Simmons, 1999). Employees inside the plant even complained about the bad taste of the tap water there; P\&G/Buckeye managers told some to add "powdered drink mixes to the water to make it more palatable" (Towles, 1999).

Another step in Towles' quest for information led her to P\&G's own documents, indicating that sinkholes beneath P\&G/Buckeye's waste-water ponds allowed untreated discharge to flow freely into the river and into the Florida Aquifer, contaminating drinking water, streams, rivers and soil in the county (Buckeye $25^{\text {th }}$ Anniversary Brochure, 1979).

Members of HOPE, with Towles in the lead, took her allegations to several Environmental Protection Agency (EPA) meetings where lawyers and lobbyists for P\&G/Buckeye pleaded for more lenient dumping laws. Towles also filed several lawsuits. The P\&G/Buckeye legal teams filed numerous counter motions holding up the suits in the legal system for years.

In a private conversation, Towles said that she and other members of HOPE began to get threats, including one call that "threatened to cut out their tongues if they didn't hush" (1999). Threats or no threats, the HOPE Foundation was ready and willing to wage war against P\&G/Buckeye (Towles, 1999). 


\section{Public Demonstration}

In an effort to demonstrate the seriousness of the issues, in June 1991, Towles and several HOPE members showed up with two fish dinners and two six-packs of water at the annual EPA meeting in Orlando, Florida. One fish dinner came from the Fenholloway River, the other dinner came from the nearby pristine Steinhatchee River. She offered Clifford Henry, a P\&G/Buckeye official, and Orlando EPA Commissioner, Kenneth Wright the dinners and explained the differences between the two. Wright asked, "which is which?” Towles declined to say and both men declined the meals (FDER, 1991). The tactic worked, the commission delayed a decision on changing dioxin standards pending further review. "We were successful that day. The commission decided they had heard and seen too much conflicting information and they didn't know what the dioxin standards should be for the Fenholloway” (Towles, 1999).

Amidst the debate over water quality in the Fenholloway River, in May 1991, owners of a mobile home park in Perry filed suit in the Federal District Court in Tallahassee against Procter and Gamble for water contamination, which they argued had decreased the value of their property. By 1992, about 100 local residents filed suit against the company for property damage, creation of a nuisance, and conspiracy with the pulp and paper mill to downplay the dangers of dioxin (Bowman and Toa 1993). As was the case in Hodges v Buckeye Cellulose Corporation (174 So. 2d 565: 1965), the case was thrown out by the District Court because the "plaintiff did not have sufficient standing in court to bring this suit contesting the constitutionality of Chapter 24952.

The tensions at the local level came to a head in April 1992 when water conflict over the Fenholloway River caught national media attention. This time, the CBS news program "60 Minutes" aired the brutality and harassment by local residents supporting the plant against those who battled against the main employer in Taylor County.

The EPA then ordered the Florida Department of Environmental Regulation (FDER) to form a health advisory committee to study matters relating to the Fenholloway River. Six months later the FDER started providing information warning residents not to consume fish caught in the river because of dioxin contamination (FDER, 1991). Despite the information, local fishermen still fish the area because, for many, it is a vital food source for one reason or another. Also the estuary of the Fenholloway River is full of crab traps that still provide crab meat to local residents and people all over the world (Action Alerts!, 1997).

\section{Alignment with Larger Organizations and Continued Effort}

Towles next move came with the help of the international organization Greenpeace. The protest to follow began an indication of information exchange:

"We organized a protest at the mill with the help of Greenpeace. We had a big stop sign and two people got locked onto the tracks. "Stop Chlorine- Save Jobs" is what the message was. We caused them a lot of grief for one entire day and stopped the chlorine train from going into the mill. We got a lot of press on it. It brought the issue to the public. We were roundly criticized for doing this, but at least it brought the idea to the community that chlorine is the problem. We've done a lot of good things. We've served contaminated fish to the Environmental Regulatory Commission and Carol Browner. We have taken live mudfish all the way to D.C. to Secretary Carol Browner's office and effluent from the river. Joe and I caught fish and I drove my pick-up truck to Washington- Joe and I drove. Took the mudfish to D. C. of course we named them, couldn't catch the names. We've been on '60 Minutes.' We've been in books, magazines, and newspapers” (Towels, 1999). 
One of HOPE's boldest moves came when members went to P\&G's home state of Ohio the day before the P\&G annual shareholders' meeting (October, 1992). Group members, accompanied by a television news crew, went directly to P\&G's CEO Edwin Artzt's house, hoping to speak to him directly. However, they never made it past the driveway. The police had Artzt's driveway blocked off.

Despite this barrier to voice their concerns, HOPE members went to the P\&G shareholders' meeting. Only Towles was allowed in the meeting. She sat in the back of the room waiting for her turn to speak, which was not until the very end of the meeting. Again, Towles had brought fish and water from Perry. But before she reached the stage, a guard confiscated both. Artzt disputed any problems with the plant, noting that $P \& G$ Artzt then ordered Towles' removal from the meeting (P\&G Transcripts, 1992). After the meeting, Towles waited for 2 days in the lobby of the P\&G headquarters for a chance to meet with Artzt, but he refused.

Members of HOPE, with Towles leadership, without question were at the front lines in providing damning information about the plant and the health risks the plant imposed on the community. HOPE members received enormous criticism from supporters of the plant, who continued to see the plant purely in economic and historical terms. For decades the plant had been the source of the area's economic base. The area has the geography and infrastructure to support the plant, including the Fenholloway River for dumping of the dioxin and the railway system to ship byproducts of the plant nationwide. In addition, the plant generated a secondary economy of suppliers and support businesses that employ other citizens of the community.

\section{Resistance and Dangers}

Others in the network faced not only criticism but bodily harm. As members of HOPE continued to disseminate information about the health hazards of the plant, P\&G/Buckeye officials gathered information about Towles and HOPE's activities and memberships. P\&G supporters even launched a smear campaign against HOPE. The Defenders of Taylor County, a group of local business leaders that supported $P \& G$, sent a letter to a statewide environmental regulator questioning HOPE's organization calling it a "pseudo-environmental cult".

Among HOPE's charter members were 15-year P\&G/Buckeye employees Linda Rowland, Stephanie McGuire, Maria Kyler and Janice Blair-Jackson.Their membership in HOPE quickly drew P\&G's attention. Rowland and McGuire owned a fishing camp, and once their membership became known, the camp was repeatedly vandalized. Animals on the farm were found dead from man-made poisons. "Women in the group began receiving threatening phone calls," Douglas Helvarg reported in his 1994 book The War Against The Greens, "including one from a caller who told them he would cut out their tongues." A local TV talk show host was taken off the air after interviewing HOPE founder Joy Towles; the station owner and a major advertiser said they had been threatened with arson. The Rowland/McGuire fishing camp was repeatedly vandalized.

Sheriff John Walker issued an affidavit charging McGuire with filing a false police report. Florida State Attorney Jerry Blair was pressured to bring charges against McGuire by Dan Simmons, Buckeye $P \& G$ public relations manager, regarding $P \& G$ 's involvement in the alleged rape. Blair told St. Petersburg Times reporter Elizabeth Wilson, “I think there's been a tremendous interest in proving that Ms. McGuire lied and I can't prove that. I think there is a perception down here that if it could be proven in court, that, instantly, the image for the P\&G plant would be changed overnight, and that is not going to happen” (Swasy, 1993).

This effectively ended their role as participants in the network.

Blair refused to prosecute. Dan Simmons said the image of P\&G hit an all-time low following the alleged incident. 


\begin{abstract}
"A woman reports that she's been raped and beaten and burned and slashed and threatened with murder. The news program 60 Minutes comes down, the F.B.I. is investigating, the Florida Department of Law Enforcement is investigating and now the Center for Disease Control and the Department of Environmental Protection is investigating our water output. The investigation lasted 18 months. The rape story was front page news, the results only made it to a few publications and never on a follow-up on 60 Minutes. The story did tremendous damage to us here at the site” (1999).
\end{abstract}

A short year later in September 1993, fire demolished McGuire's camp. Simmons said the connection between the alleged rape and the investigation by the DEP and the CDC into P\&G water discharge had a bigger impact on the company. According to Simmons:

"The stories on the water contamination were a bigger distraction for the company than the rape and it took longer to resolve. The DEP and theCDC reports water wells in the community were contaminated. We immediately made bottled water available to people and probably spent a million dollars on bottled water. We figured the issue would be cleared up in a couple of weeks. It took several years” (1999).

\title{
Current Situation
}

HOPE members continue their fight for a better environment, but the pulp mill continues to dump 50 million gallons of effluent into the Fenholloway River. The Perry saga embodies the complicated politics of environmental justice and its economic impact. It is a conflict over science, law, poverty, economic development and the environment. The P\&G/Buckeye Plant and HOPE represent the conflict between economic stability in a community and the rights of citizens to live in a clean and safe environment. It embodies certain prerogatives of U.S. citizenship which presuppose the availability of information necessary to make an informed decision regarding one's life and residential conditions.

In 1994, P\&G removed its name, but not its investments, from the mill. Bob Cannon, a former P\&G executive bought a controlling interest in the P\&G pulp mill. The price included a $\$ 40$ million 5-year plan to restore the Fenholloway River to "fishable and swimmable" condition and a new name, Buckeye Cellulose. Clean-up of the river and soil, however, is on hold pending additional discussion of which technologies could achieve the best environmental results for the river. Board members of P\&G bought the company and changed the name to Buckeye. However, P\&G receives all the profits from the plant (Florida EPA Review, 1994).

Although successful in bringing about a measure of awareness and public indignation, the membership of HOPE sensed that is would fall short of its goal to close the plant entirely. Instead, a new tactic was initiated in which HOPE would fight to have the plant adhere to state and federal standards regarding discharge from a plant into a river. This would avoid the conflict of economic issues and concerns facing the small community. The campaign by HOPE now focused on making the Fenholloway River fishable and swimmable. The goal is to look at the technical and economic possibility of additional treatment alternatives for the P7G/Buckeye mill that will improve the quality of the effluent, and help the river meet fishable and swimmable water quality standards.

"We have always been very interested in seeing the cleanup of the Fenholloway River," said Jessica Landman, senior counsel with the Natural Resources Defense Council (NRDC). "This is a river whose time has come to enter the land of the living. I am hopeful that there are a lot of things that Buckeye can do to reduce their loadings at a cost that is affordable" (1998). 
The tactic on paper worked; officially the river was reclassified to a Class III on January 1, 1998. The reclassification to a Class III river should force the plant to adhere to more stringent pollution guidelines.

Buckeye spokesperson Dan Simmons has said that the company is working on solutions (Simmons, 1999). For example, in 1995, according to Simmons, the company spent \$3 million on a 3year study. The study found that dioxin levels in the water and soil are coming down, but the dissolved oxygen levels are the same, "making the river less hazardous for humans but still environmentally unfriendly for aquatic life.” Simmons remarked, “The most dangerous things in the river are the alligators" (Simmons, 1999).

Buckeye is now working with the Department of Environmental Protection (DEP) in an attempt to develop a solution that will fall in line with Class III River regulations. DEP's Use of Attainability Analysis (UAA) suggested four alternatives for this classification change: 1) in-mill process change; 2) relocation of the discharge point closer to the mouth of the river (a pipeline); 3 ) oxygen injection into the discharge; and 4) establishment of wetlands as the head waters (DEP \& Buckeye, 1998). The EPA, DEP and Buckeye agreed with the second suggestion: to build an 18mile, \$15 million pipeline from the plant directly to the Gulf of Mexico, virtually dumping the entire flow of the river and the discharge directly into the Gulf.

This proposal served to ignite the membership of HOPE to mobilize the network for purpose of confrontation through publicity of the impending construction. First, they filed a lawsuit that requested an evidentiary hearing with the EPA Regional Administrator to contest certain provisions of Buckeye's Permit to build the pipline. Second, HOPE sent out a press release, locally and nation, and began a phone-tree system notifying residents from Perry to the small fishing communities of the Gulf of Mexico of the reclassification of the river. HOPE's press release claimed the dumping of the toxic effluent to the Gulf of Mexico is short-sighted solution. "A pipeline cannot solve the serious environmental problems caused by the mill-the contamination of the ground water, the Fenholloway River, the Florida Aquifer, and the soil” (Livingston, 1999). Professor Livingston said the river is finished.

\section{The Information Gateway of Environmental Justice}

The Environmental Protection Agency states that the goal of environmental justice is to ensure that "all people, regardless of race, national origin or income, are protected from disproportionate impacts of environmental hazards" (EPA Section 309.1.3). Environmental justice proponents say that discrimination is woven into the landscape in ways never officially acknowledged. "It can be found in cumulative results of decisions made over decades by agencies that traditionally paid little attention to the concerns of minorities or the poor: zoning boards, economic development bodies, and transit and environmental agencies” (Helvarg, 1994). This was certainly true of the case of HOPE and its operation in Perry, community groups have exposed these inequities and by doing so, have seen to it that pressure has been applied on government officials with mixed results. Within the realm of environmental activism, Margaret Mead summed up the conflict under the heading of information exchange: "Information needs and exchanges appear when people are members of groups from which they have no means of escape or of self-betterment, due to ignorance, government regulations, or lack of a culturally deprived belief that escape is possible” (Mead, 1962).

Mead's summation embraces the case of Perry, Florida in which one person served as the catalyst for community action by serving as a data gatherer and information provider for vital matters. Joy Towles, as an activist for truth, raised widespread consciousness and knowledge about the issues and clarified health concerns to the community. With the help of environmental groups such as HOPE, and mainstream organizations such as LEAF and Greenpeace, the media in general, and 
the DEP, residents have become more conscious of environmental justice, and their prerogatives to pursue a healthy way of life. At the heart of the environmental justice movement is its strong belief in the right of citizens to participate in environmental decision-making. Community rightto-know laws, citizens enforcement provisions in federal and state legislation, and local input in waste clean-up and the placement of toxic releasing corporations are key issues for the environmental justice movement.

In analyzing the problem associated with providing for the public good, the question of what and how much information is going to be needed. It is clear that problems are resolved by sharing information and power (Pasquero, 1991). The question of social and community values are highlighted, and must be considered as factors weighing in on such decisions. In some situations, information sharing and the forming of partnerships and networks may be as important as researching a solution to a particular problem (O’Leary, 1995). It was shown to be effective in providing needed information to the community of Perry, Florida at a critical time. This enabled the residents to finally become aware and develop a fuller understanding of the level of toxic hazards they faced with the continued and unabated daily work routines of the town's largest single employer. In helping its citizens become aware of such conditions, the required criteria of a just society has been reached. With such awareness, citizens can then make informed decisions regarding their future.

In summary, first it was clear that HOPE was successful in creating a following, developing, then enhancing its membership by utilizing local information channels like the local newspaper, networking with family and community members and holding both informal and formal public informational meetings.

Second, HOPE members began to network outside of the primary organization by reaching out to secondary sources for information and information exchange. They gathered and exchanged information from main government outlets (the EPA \& DEP) and national and statewide mainstream environmental organizations (Greenpeace and LEAF). This data was collected, organized, analyzed, and reported through both newspaper articles and public meetings.

HOPE, with the assistance of community leaders and P\&G/Buckeye insiders broadcast enough concern and consciousness in the community of Perry, Florida to help citizens understand why environmental justice issues are vital to the community's health. The organization brought attention to the contaminated water in area wells, and made sure people of the community were aware of the dangers of fishing or eating fish from the Fenholloway. Members brought attention both national (60 Minutes) and statewide (Tallahassee Democrat, St. Petersburg Times and Florida Public Radio) to the environmental issues facing the community of Taylor County, and scored a victory of sorts for the quest for environmental justice.

As an information provider, HOPE brought knowledge and clarified environmental issues to the community of Perry, Florida, a community, like many others faced with low economy levels and low education levels. Since the citizens were relatively unaware of the environmental toxins abounding In their areas of residence, this was an immeasurable act of conscience and self preservation undertaken at first by very few dedicated and brave individuals. By being able to communicate with the people of Perry on their level and with a language they could understand, real enlightenment resulted in definite changes toward a more healthy environment. This was achieved because of the life-long ties to the community held by members of HOPE. Simply, they spoke the local language.

The members of HOPE remain close to each other. They are long-time members of the community with family ties dating several generations. This link only strengthens the influence of the information received or disseminated. Trusting the information and the information providers is 
essential when a community is facing an issue that has the potential to disturb a way of life, the income of the community and the health of a community.

In summary, this section has treated the impact of information exchange on the effort to establish environmental justice in Perry, Florida. Environmental decisions are often made by relying upon scientific and economic expert opinions and information-to the exclusions of the people the information is impacting. Environmental values expressed by the general population in terms laden with emotions are often discounted in the environmental decision-making process (Caldwell \& Schrader-Frechette, 1993). This account of personal experiences of the HOPE Foundation demonstrates the human impact of one environmental disaster, the impact on right-to-know laws, and linkages to other environmental justice movements. It is representative of the continuing impact of environmental activism on federal and state environmental laws. If laws, both federal and state, are to be changed, the process of information exchange by and between citizens is the key

Most of all, this work represents the value of communication and the dissemination of needed information of vital nature to those who are affected by public policy. Through information and knowledge-sharing, it has made it possible for citizens to exercise informed choice when decisions are to be made regarding necessary trade-offs they must make in choosing residential areas and vocations.

\section{Summary And Conclusions}

"We can't protect our health and the environment without finding the courage to change the way the government works. To begin this process of change, we have to create a national debate, community by community, on the nature of our government and our society. We have to explore how people become powerless as the corporations become more powerful. We have to discuss why our government protects the right to pollute more than it protects our health. We have to figure out how to speak honestly to rebuild our democracy” (Lois Gibbs, Dying from Dioxin, 1988)

\section{Information Gathering of HOPE}

Information gathering began with its founder Joy Towles and her need to understand what was happening to the environment in her community. She began talking with neighbors, workers at the plant and the public relations department at the plant.

Her first move was taking put an ad in the local paper asking those who felt impacted by the mill to contact her. In affect this was the beginning of HOPE as a grassroots organization to seek environmental justice for the community. Person-to-person communication began with people who would soon to become members of this social network. The network than began a chain of information gathering routines that included reaching further outside the immediate network. They sought professional and expert advice from the tri-state based environmental foundation, Legal Environmental Assistance Foundation, and further support from research conducted by the Aquatic Center on Research and Resource Management at Florida State University.

HOPE members then traveled out-of-state to Ohio, the headquarters of the P\&G/Buckeye Cellulose Plant to bring the attention of the stockholders to the plight of Perry, Florida. This insured coverage in local and national media.

\section{Environmental Justice}

American communities face a vast number of problems in our communities and in our environment. Pollution runs rampant through our global environment. The air we breathe, the water we drink and the food we eat are all at risk. The extent of these problems can be overwhelming, and 
it can be difficult to help solve environmental and other social problems. Awareness and communication within small groups are two elements to open public debate facing so many minorities.

The public is increasingly aware of the effects of industrial production on the environment and the public welfare. Despite corporate public relations efforts, polls show that a large number of people in the United States are growing increasingly distrustful of anything corporations say (Meeker-Lowry, 1995).

Access to information is key to the environmental movement. To cope with complex situations, such as environmental justice, there is a need to utilize all the relevant and useful knowledge that exists, partly to understand the situation fully and partly to help the stakeholders change it. A great deal of potentially useful knowledge is still under-utilized by people responsible for coping with complex situations (Kochen, 1992). Scientists readily admit that our knowledge of the environment is limited because human society is also complex (Caldwell, 1993).

Information and education, according to Robert Bullard (1998), are the two key areas in which grassroots organizations must participate:

"We're not saying that people are evil and that these organizations are setting out to do harm, but we're saying that we have to educate ourselves and learn about each other. We have to cross those boundaries and go on the other side of the tracks, go to the meetings downtown and learn from each other. That's what we've been doing for the last twenty years: trying to get a handle on how we can work together in a principled way. And in 1991 we had the first national people of color environmental leadership summit and we developed 17 principles of environmental justice. Basically, how can we as people of color, working class people and poor people work on agendas that at the same time may conflict with the larger agendas of the big groups” (Bullard, 1998).

When Lois Gibbs learned in 1978 that 20,000 tons of toxic chemicals were buried under her Niagara Falls, New York, neighborhood, she tried to make sense of all the information and scientific names. She turned to her local library, wading through medical journals and old newspaper articles to understand the chemicals and the diseases they caused. She credits her success of the closing of Love Canal to the open channels of information found in libraries, understanding the Freedom of Information Act, and public and open discourse (Gibbs, 1999).

In addition, communities now have a little more information for attending to local business issues because of the federal Community Right to Know and the 1990 Toxic Pollution Prevention Act (Sobol, 1991). The Right to Know law requires manufacturers to report their emissions to air, land, and water of over 300 toxic chemicals (Emergency Planning and Community Right to Know Act, 42 U.S.C. § 1100111050 [1988 and Supp. V 1993]). The Toxic Pollution Prevention Act requires that any facility that is required to report data must also report on its toxic pollution prevention (Pollution Prevention Act, 42 U.S.C.A. $§ 13101$ to 13109). The growth in available information has provided a powerful tool for exposing the truth of environmental degradation.

Government officials and agencies have exercised their power to exploit the less politically influential, the less informed and the poorer members of society. Rather than receiving protection from a democratic system designed to protect the minority voice, the ethnic and racial minority communities became a convenient scapegoat for difficult political decisions. Pollution Prevention Act, 42) As public awareness grows, minority opposition to environmental racism will continue until the neighborhoods in which they live are no longer treated as safe places for polluters.

\section{Conclusions}

Much remains to be learned about environmental health and environmental justice. Great strides need to be taken in terms of interrelated topics of research and education before society can en- 
sure environmental justice in its broadest sense. Environmental justice needs to become a higher priority in the fields of public health, research and communication.

The grassroots environmental movement involves women, the poor, and people of color confronting environmental hazards in their neighborhoods. Affected groups have been successful in bringing changes to the environmental agenda through demonstrations, consumer boycotts, shareholder suits, and nonviolent protests. Protests against incinerators and toxic industries in minority neighborhoods have forged a powerful coalition that has gained many important victories through local protests and marches, lawsuits, attendance at hearings, notification of voters, demonstrations, and picketing.

Environmental justice activists and academics alike need to join forces to form a much stronger, action-oriented movement. The voices on environmental justice and equality under the Carter and Clinton Administrations exerted some influence in policy making, as in the case of the federal Environmental Protection Agency (EPA), the Agency for Toxic Substances and Disease Registry (ATSDT), and the National Institute for Environmental Health Services (NIEHS).

As a social movement, environmental justice, has made a mark on the political landscape with the above noted agencies. Also, new methods among small organizations are developing reflecting a clear pattern among various groups:

1. Collaboration among various communities, interest groups, and government agencies. Direct evidence of this pattern is seen within this report. The Center for Health, Environmental and Justice, the EPA, Florida's DEP, and various small grassroots organizations, including CATE in Pensacola, Florida, exchanged information to further HOPE's approach to make Perry a healthier place to live and work.

2. Deliberation among and within communities, interest groups and levels of government. There is clear direct evidence with regards to the Perry study. The EPA, The Florida State University Aquatic Institution, and the Legal Environmental Foundation all joined together to share information with each other and with the main network HOPE.

This element is vital for information within a community:

"What I would tell folks if they want to get involved is the first thing they need to do is talk to some other people, find out what is in your community and talk with other people. Most people belong to a church or a Girl Scouts or PTA, I mean people have community groups that they could start talking to folks about what the problem is. And one conversation will lead to another conversation and soon you will find that the whole community is very concerned about that issue as well and willing to get involved. A single individual can do a spark in a community, get people educated about the problem, get them motivated and energized and help them figure out how to go about making change. Then those people in the community can actually achieve change. I think historically we always thought about justice being won by hundreds of thousands or millions of people marching on Washington, DC or the state capitol, and that is not how change happens. Change in this country happens by people changing their own community, and so an individual will find a problem, will educate their community and mobilize the community to find the answers and putting pressure on decision makers. And it is extremely successful, and has been all across the country" (Gibbs, 1999).

3.An extensive use of nontraditional tactics including protests, newspaper ads, and national recognition by CBS on "60 Minutes," networking through community sources including area churches. 
4.Focusing on long-term solutions for the betterment of the entire community. The Buckeye Cellulose Plant wants to save jobs in Taylor County and save the Fenholloway River by bypassing the river and building a tunnel to dump the waste from the mill directly into the Gulf of Mexico. The proposed solution had yet to be finalized as of October 2003.

Rather than relying on top-down government control to address specific needs, communities themselves are learning how to supplement the need for direct government or corporate assistance in addressing community development. The emerging environmental justice movement, for instance, has engendered a shift in local leadership as women, people of color, and indigenous people play a more active role in their communities (Collie \& Collin, 1994).

\section{References:}

Adler, P.A., \& Alder, P. (1988, Sept). Intense loyalty in organizations: A case study of college athletics. Administrative Science Quarterly, 33, 401-417.

Agency for Toxic Substances and Disease Registry (ATSDR). (1988). The nature and extent of lead poisoning in children in the United States: A Report to Congress. Atlanta, GA: Center for Disease Control.

Ambler, M. (1991). On the reservations: No haste, no waste. Planning, 57 (11), 26-29.

Angel, R. (1992). Source: International-Migration-Review, 1(97), 111-132.

Bachrach, P., \& Botwinick, A. (1992). Power and empowerment: A radical theory of participatory democracy. Philadelphia: Temple University Press.

Basquet, C. R., Horm, J. W., Gibbs, T., \& Greenwald, P. (1991). Socioeconomic factors and cancer incidence among blacks and whites. Journal of the National Cancer Institute, 83, 551-557.

Bates, F. L., \& Peacock, W. G. (1989). An evaluation of agency housing programs. In F. L. Bates (Ed.), Recovery, change, and development (pps. 497-623). Athens, GA: Department of Sociology, University of Georgia.

Baugh, J. A. (1991). African-Americans and the environment: A review essay. Policy Studies Journal, 19 (2), 183-191.

Bennet, J. (1993). Hispanic voters and the politics of sludge. New York Times, March 5, B1.

Berry, W. (1992). The environmental justice movement: No shortage of environmental volunteers. EPA Journal, 18 (1), 23-25.

Bingham, G. (1986). Resolving environmental disputes: A decade of experience. Washington, DC: The Conservation Foundation.

Bogdonoff, S. (1995). Consensus building to write environmentally responsive rules for Maine's new transportation policy. In J. Blackburn \& W. Bruce (Eds.), Quorum books: Westport, CT. Economy, environment, and technology: A socioeconomic approach. Armonk, NY: M. E. Sharpe.

Booth, A. L., \& Jacobs, H. M. (1990). Ties that bind: Native American beliefs as a foundation for environment consciousness. Environmental Ethics, 12 (1), 27-43.

Brockovich, E. (2001, April 18). Personal Interview. Environmentalist.

Brown, D. (1993). Ethics, science and environmental regulation. In S. J. Armstrong \& R. G. Botzer (Eds.), Environmental ethics: Divergence and convergence (pp. 152-161). New York: McGraw-Hill.

Bryant, B., \& Mohai, P. (1992a). Environmental injustice: Weighing race and class as factors in the distribution of environmental hazards. University of Colorado Law Review Journal, 18(1), 9-10.

Bryant, B., \& Mohai, P. (1992b). Race and the incidence of environmental hazards. Boulder, CO: Westview Press. Brynes, K. (1998). Environmental racism. Crisis, 98 (4): 14-17, 31-32. 
Bullard, R. D. (1990). Dumping in Dixie: Race, class, and environmental equity. Boulder, CO: Westview Press.

Bullard, R. D. (1992). The case for environmental equity/justice and its historical perspective. Speaker, National People of Color Environmental Leadership Summit. Proceedings. New York: United Church of Christ Commission for Racial Justice, 1992.

Bullard, R. D., (Ed.). (1993a). Confronting environmental racism: Voices from the grassroots. Boston: South End Press.

Bullard, R.D. (1993b). Politics of race and pollution. Sociological Inquiry, 53(Spring), 273-288.

Bullard, R. D. (1993c). The threat of environmental racism. National Resources and Environment, 7(3), 2326, 55-56.

Bullard, R. D., Lewis, J., \& Chavis, B. F. (Eds.). (1996). Unequal protection: Environmental justice and communities of color. San Francisco: Sierra Club Books.

Bulletin of Equality. (1994). Accessed June 10, 1997: httl://www/ehl/uh. edu/ eih/94Bulletinequality.html.

Burgess, G., \& Burgess, H. (1995). Beyond the limits: Dispute resolution of intractable environmental conflicts. In J. Blackburn \& W. Bruce (Eds.), Mediating environmental conflicts. Westport, CT: Quorum Books.

Cahn, M. (1995). Environmental deceptions: The tension between liberalism and environmental policymaking in the United States. Energy and the politics of consumption. Albany, NY: SUNY Press.

Caldwell, L. (1994). International environmental policy law. In L. Caldwell, \& K. Schrader-Frenchette (Eds.), Policy for land: Law and ethics . Lanham, MD: Roman \& Littlefield.

Caldwell, L.K. (1989). A constitutional law for the environment. A critique of the failings of the American National Environmental Protection Act and discussion of the need to enshrine environmental protection in the American Constitution. Environment, 10, 6-11, 25-28.

Capek, S. (1993). The environmental justice frame: A conceptual discussion and an application. Social Problems, 40 (1), 5-24.

Capra, F. (1996). The web of life. New York, NY: Doubleday.

Capra, F., \& Steindl-Rast, D. (1991). Belonging to the universe: Explorations on the frontiers of science and spirituality. San Francisco: Harper.

Caron Construction \& Environmental, Inc. v. Jeffrey Brusco, Trustee of Three Hole Trust et al. (1989). Docket No. Ca 00-0098c. Parties: Caron Construction Environmental, Inc. v. Planning Board of Cambridge, 27 Mass. App. Ct. 491, 493.

Carpenter, S. L. (1998). Solving community problems by consensus. Washington, DC: Program for Community Solving, National Civic League.

Carson, R. (1993). Silent Spring. Boston: Houghton Mifflin Company.

Carter, J. (1980, October 1). Speech in New York State.

Chavis, B. (1987). United Church of Christ Commission on Racial Justice. Toxic wastes and race in the United States. New York: United Church of Christ.

Church, T., \& Nakamura, R. (1993) Cleaning up the mess. Washington, DC: Brookings.

Citizen's Clearinghouse for Hazardous Waste. (1993). Ten Years of Triumph. Arlington, VA: CCHW.

Citizens Program for the Chesapeake Bay, Inc. (1993, October). Choices for the Chesapeake: An action agenda. Workshop Recommendations.

Cole, R. E. (1985). The macro politics of organizational change: A comparative analysis of the spread of small group activities. Administrative Science_Quarterly, 30, 560-585. 
Information Exchange and Environmental Justice

Colquette, K. M., \& Henry-Robertson, E. A. (1991). Environmental racism: The causes, consequences and commendations. Tulane Environmental Law Journal 5 (1), 153-207.

Commission for Racial Justice, United Church of Christ. (1987). Toxic wastes and race in the United States: A national report on the racial and socio-economic characteristics of communities with hazardous wastes sites. New York: Public Data Access., xiii-xvi.

Coyle, M. (1985). Health effects of agricultural production: I-The health of agricultural workers. Journal of Public Health Policy, $\underline{6}$, 349-370.

Davidoff, P. (1973). Advocacy and pluralism in planning. Journal of the American Institute of Planners, 31. Reprinted in A. Faludi (Ed.), A reader in planning theory (pp. 227-289). New York: Pargamon.

De La Pesa, N. (1991, March). Fighting for the environment. Hispanic Review, 18-23.

Department of Health and Human Services (HHS). (1991). Health status of minorities and low-income groups ( $3^{\text {rd }}$ ed.).

Dowie, M. (1992). The new environmentalism. Utne Reader, 52, 104-111.

Dowie, M. (1995). Losing ground: American environmentalism at the close of the twentieth century. Cambridge, MA: MIT Press.

Environmental Institute of Houston. (1994). Environmental equity: A criticalreview from all perspectives. University of Houston. 1994 Bulletin of Equality. Accessed June 10, 1997.

hht://www/enl/uh.edu/eih/94Bulletinequity.html.

Environmental Law Reporter. (1989). An annotated legislative history of the Superfund Amendments and Reauthoritization Act of 1986 (SARA). In Superfund deskbook. Washington, DC: Environmental Law Institute.

Environmental Protection Agency (EPA). (1990). Reducing risk: Setting priorities and strategies for environmental protection. Washington, DC: Science Advisory Board, SAB-EC-90-021.

EPA Press Release. (1990, May 15). EPA Administrator William K. Reilly to Lois Gibbs of Citizens Clearinghouse for Hazardous Wastes, Inc. Retrieved from http://www.epa.gov/history/topics/lovecanal/O

EPA Regional Report. (1998). Washington, D.C. \#MD980685226.

General Accounting Office (GAO). (1983). Siting of hazardous waste landfills and their correlation with racial and economic status of surrounding communities. Washington, DC: GAO/RCED-83-168.

Gibbs, L. (1980, May). Living in a toxic world: Love Canal, and the environmental justice movement.

Gibbs, L. (1993). Citizens clearinghouse for hazardous waste: Ten years of triumph. Arlington, VA: CCHW.

Gibbs, L. (1995). Environmental community organizing. In S. Langton (Ed.), Environmental leadership (pp. 6-11).

Gibbs, L. (2001, June). Director of Citizens Clearinghouse of Hazardous Waste. Personal Interview.

Gibbs, L., Regenstein, L. G., \& Smith, D. (1994). In W. P. Cunningham et al. (Eds.), Environmental encyclopedia (p. 374). Detroit: Gale Research, Inc.

Glickman, T. S. (1994, Summer). Measuring environmental equity with geographical information systems. Washington, DC: Resources for the Future Newsletter.

Glickman, T. S., \& Hersh, R. (1995). Evaluating environmental equity: The impacts of industrial hazards on selected social groups in Allegheny County, Pennsylvania. Washington, DC: Resources for the Future.

Godsil, R. D. (1991). Remedying environmental racism. Michigan Law Review, 90 (2), 394-427. 
Gottlieb, L. D. (1991). Conservation of rare and endangered plants: Principles and prospects. In D. A. Falk, \& K. E. Holsinger (Eds.), Genetics and conservation of rare plants (pp. 81-88 and 194-208). New York, New York: Oxford University Press.

Gould, J. D. (1986) Human factors perspectives on human-computer interaction: Selections from Proceedings of Human Factors and Ergonomics Society Annual Meeting, pp. 48-50. Santa Monica, CA.

Gould, J. D. (1988). How to design usable systems. In M. Helander (Ed.), Handbook of human-computer interaction ( $2^{\text {nd }}$ ed.) (pp. 93-121). San Francisco, CA: Morgan Kaufmann Publishers.

Grad, T. (1982). A legislative history of the comprehensive environmental response, compensation and liability ("Superfund") Act of 1980. Columbia Journal of Environmental Law, 8, 1-36.

Greenburg, S. (1993). The computer user as toolsmith: The use, reuse, and organization of computer-base tools. Cambridge, MA: Cambridge University Press.

Grossman, K. (1991). Environmental racism. Crisis, 98 (4), 14-17, 31-32.

Habermas, J. (1985). The theory of communicative action. 1 and 2, trans. T. McCarthy. Boston: Beacon.

Hadden, S. (1989). A citizen's right to know: Risk communication and public policy. Boulder: Westview Press.

Hauserman, J. (1997). Gulf may get river’s waste. St. Petersburg Times, January 12, A1.

Hauserman, J. (December, 2001). Freelance Environmental Reporter. Personal Interview.

Hayes, A. S. (1991). New specialty helps poor fight pollution. Wall Street Journal, October 3, 1991, p. 3.

Hoberg, G. (1992). Pluralism by design environmental policy and the American regulatory state. New York: Praeger Publishers.

Hofrichter, R., (Ed.). (1993). Toxic struggles: The theory and practice of environmental justice. Philadelphia: New Society Publishers.

Johnson, R. F. (1989). Risk communication and regulatory culture clash. Washington, DC: Office of Policy Analysis, U.S. Environmental Protection Agency.

Jordan, C., \& Snow, D. (1992). Diversification, minorities, and the mainstream environmental movement. In D. Snow (Ed.), Voices from the environmental movement (pp. 71-109). Washington, DC: Island Press.

Kempton, W., Boster, J., \& Hartley, J. (1995). Environmental values in American culture. Cambridge, MA: MIT Press.

Klase, K. (1995). The problems of designing environmental mediation for small communities. In. J. Blackburn, \& W. Bruce (Eds.), Mediating environmental conflicts. Westport, CT: Quorum Books.

Kramer, D. (1972). Participatory democracy: Developing ideals of the political left. Cambridge, MA: Schenkman Publishing Co.

Kweit, M., \& Kweit, R. (1987). The politics of policy analysis: The role of citizen participation in analytic decision making. In J. Desario, \& S. Langton (Eds.), Citizen participation in public decision making . New York: Greenwood Press.

Langston, S. (Ed.). (1998). A Sourcebook for staff and volunteer leaders of environmental organizations. Lexington, KY:

Laws of Florida, Chapter 24952-no. 1338. House Bill no. 242, 1947.

Lee, C. (1990). Toxic waste and race in the United States. In B. Bryant, \& P. Mohai (Eds.), The proceedings of the Michigan Conference on Race and the Incidence of Environmental Hazards (pp. 41-52). Boston: South Bend End Press.

Legal Environmental Assistant Foundation (LEAF) Mission Statement. (2000). Tallahassee, Florida. 
Lester, A., \& Milburn-Lauer, _. (1994). Race, class and environmental quality: An examination of environmental racism in the American states. Colorado State University.

Link, T. (1993). Environmental racism/environmental equity. Green Library Journal: Environmental topics in the information world, 2(1), 17-22.

Mann, E. (1991). L.A.'s Lethal Air: New strategies for policy, organizing and action. Los Angeles: Labor/Community Strategy Center.

Maraniss, D., \& Weisskopf, M. (1987, December 1). Jobs and illness in the Petrochemical Corridor. Washington Post, p. 1.

Mazmanian, D., \& Morell, D. (1991). EPA: Coping with the new political economic order. Environmental Law, 21(4), 1477-91.

Mazmanian, D., \& Morell, D. (1992). Beyond superfailure: America's toxins $\quad$ policy for the 1990s. Boulder: Westview.

Mazmanian, D., \& Morell, D. (1994). The 'NIMBY' syndrome: Facility sitting and the failure of Democratic discourse. In N. Vig, \& M. Kraft (Eds.), Environmental policy in the 1990s (pp. 233-49), (2 ${ }^{\text {nd }}$ ed.). Washington, DC: Congressional Quarterly Press.

Mead, M. (1962, October). Foreign affairs. New York.

Merchant, C. (1992). Radical ecology: The search to a livable world. New York: Routledge.

Mohai, P. (1990). Black environmentalism. Social Science Quarterly, 71 (4), 744-765b.

Mohai, P., \& Bunyn, B. (1992). Race, poverty, and the environment. EPA Journal, 18(1), 6-8.

National Center for Health Statistics (NCHS). (1990, January). Health of black and white Americans, 198587, Series 10: Data from the National Health Interview Survey, No. 171, U.S. Department of Health and Human Services. United Church of Christ Commission on Racial Justice, 1987.

National Environment Policy Act. (1998).

National Institute for Environmental Health Sciences. (1995). Proceedings of the Health and Research Needs to Ensure Environmental Justice Symposium. Research Triangle Park, NC: NIEHS.

National Institute of Medicine, National Report, 1999.

Noe, F. P., \& Snow, R. (1989). Hispanic cultural influence on environmental concerns. Journal of Environmental Education, 21 (2), 27-34.

NPDES Permit No. FL0000876. United States Environmental Protection Agency.

O’Leary, R. (1995). Environmental mediation: What do we know and how do we know it? In J. Blackburn, \& W. Bruce (Eds.), Mediating environmental conflicts. Westport, CT: Quorum Books.

Pena, D., \& Gallegos, J. (1997). Local knowledge and collaborative environmental action research. In P. Nyden, A. Figert, M. Shibley, \& D. Burrows (Eds.), Building community: Social science in action. Thousand Oaks, CA: Pine Forge.

Perkins, J. (1992). Recognizing and attacking environmental racism. Clearinghouse Review, 26(4), 389397.

Perry-Taylor County Chamber of Commerce, 1995.

Popper, F. J. (1985, March). The environmentalist and the LULU. Environment, 27.

Prout, L. R. (1992). The toxic avengers. EPA Journal, 18(1), 48-49.

Reed, C. (1995). Mediation and the new environmental agenda. In J. Blackburn, \& W. Bruce (Eds.), Mediating environmental conflicts. Westport, CT: Quorum Books. 
Reilly, T. (1998). Communities in conflict: Resolving differences through collaborative efforts in environmental planning and human service delivery. Journal of Sociology and Social Welfare, 25 (3), 115142.

Roy, M. (1992). Pollution, prevention, organizational culture, and social learning. Environmental Law, 22(1), 189-251.

Ruben, G. (1991). Grave reservations: Waste company proposals targeting native American lands are meeting with a growing pattern of resistance. Environmental Action, 23(1), 12-15.

Russell, D. (1989). Environmental racism: Minority communities and their battle against toxic. Amicus Journal, 11(2), 22-32.

Satchell, M. (1992). A whiff of discrimination? US News \& World Report, 112(17), 34-35.

Selin, S., \& Chavez, D. (1995). Developing a collaborative model for environmental planning and management. Environmental Management, 19(2), 189-195.

Simmons, D. (1999). Lobbyist for Procter \& Gamble in the State of Florida.

Sinclair, M.P. (1991). The role of citizen public interest groups in the decision- making process of a science-intensive culture.

Snow, D. (1992). Inside the environmental movement: Meeting the leadership challenge. Washington, DC: Island Press.

State of Florida. (1991, April). Ground Water Investigation.

Suro, R. Pollution-weary minorities try civil rights tack. The New York Times, January 11, 1993, p. A1.

Szasz, A. (1994). Ecopopulism: Toxic waste and the movement for environmental populism. Minneapolis: University of Minnesota Press.

Toxic Wastes and Race in the United States. New York: United Church of Christ. D. Wernette, \& L. Nieves. (1991). Minorities and air pollution: A preliminary Geo-Demographic analysis, presented at the Socioeconomic Research Analysis Conference - II, June 27-28.

Truax, H. (1992). Untold suffering. Environmental Action, 24(3), 14-17.

Tsao, N. (1992). Ameliorating environmental racism: A citizens' guide to combating the discriminatory siting of toxic waste dumps. New York University Law Review, 67(2), 366-418.

United Church of Christ Commission on Racial Justice. (1987). Toxic wastes and race in the United States. New York: United Church of Christ.

U.S. News and World Report. (2000, June 18).

Wallis, A. (1996). Toward a paradigm of community-making. National Civic Review, 85, 34.47.

Webster, D. (1992). Sweet home Arkansas. Utne Reader, 52, 112-116.

Williams, B., \& Matheny, A. (1995). Democracy, dialogue and social regulation. New York: United Church of Christ.

Zimmerman, M. E. (1994). Contesting earth's future: Radical ecology and postmodernity. Berkeley, CA: University of California Press. 


\section{Biography}

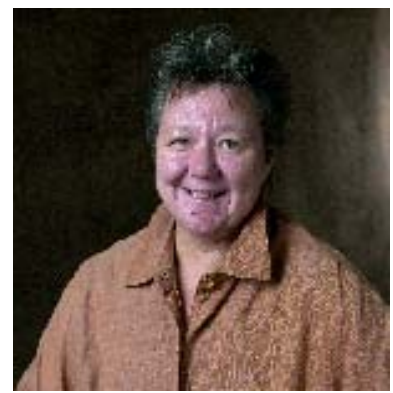

Gloria G. Horning, Ph.D. has been working on AIDS and Environmental communication Issues for more than 13 years. She has produced/written and directed three AIDS documentaries and is in the process of producing her first full-length documentary on environment issues facing minorities in the deep South.

Professor Horning is presently teaching in the Electronic Media program at Northern Arizona University. She brings to the NAU/EM curriculum 13 years higher-education experience and nearly 12 years experience as a news producer and director for NBC and CBS affiliates. 